\title{
A performance profile of dairying in Bangladesh - programs, policies and way forwards
}

\author{
KS Huque* \\ Bangladesh Livestock Research Institute, Savar, Dhaka 1341, Bangladesh
}

\begin{abstract}
A national dairy performance profile is developed and described in this article reviewing the performance of the smallholder dairy production system, its backward and forward supports and existing development programs and policies; and based on the analyses further way forwards are described concisely. Inclusion of quality genes over the past decades of crossbreeding resulted in crossbred cows of about $47 \%$ with an average lactation yield of 1838 litre in 266 days, while the similar performance of a local cow is 619 litre in 230 days, respectively. Further, population increase of crossbred cows may increase milk production horizontally at the expense of genetic dilution. Nevertheless, a common plane of nutrition with the availability of 54.7 and $22.5 \%$ of annual requirement of metabolizable energy and digestible crude protein, respectively, may not uphold vertical improvement of dairying in Bangladesh. Local buffaloes, on the other hand, having only 635 litre lactation yield in 227 days share only $2.29 \%$ of the total liquid milk production, and unlocking potentials of dairy Buffaloes may boost milk production further. Creation of an enabling environment for multiplication of private dairy feed industry and community fodder production system; policy support to private entrepreneurs remain active in dairy marketing; reviewing and revising of present domestic support to dairy; establishment of easy credit and capital support to rural dairy farmers; strengthening of coordinated backward services of the public and private sector; capacity strengthening for dairy extension, research and education and human resource development are the way forwards for expediting the dairy industry in the country. An important and effective support to dairy would be capacity strengthening through establishing an autonomous organization for an enhanced coordinated support to both public and private sector with a clear authoritative mandate for setting policy priorities, institutional structures, priorities for research and extension and appropriation of adequate financial resources. Considering all the above suggestions an action plan may be formulated to meet the growing demand of milk in the present changing and challenging socio-economic condition of the country.
\end{abstract}

\begin{tabular}{l}
\hline Key words: Bangladesh, dairying, programmes, policies, way forwards \\
\hline Bangladesh Animal Husbandry Association. All rights reserved. Bang. J. Anim. Sci. 2011. 43 (2): 81-103
\end{tabular}

\section{Dairying in Bangladesh}

\section{Smallholder dairying}

The smallholder dairy production in Bangladesh through its economic contributions shares $18.6 \%$ of the animal farming gross domestic product (GDP) that shares $2.41 \%$ of the national GDP; and it excludes livelihood contributions of the dairy farming in the country. The livelihood of the land-poor rural farmers depends on their income sources other than the land, and livestock play a vital role here. About $52.3 \%$ of the total cattle owner has $\leq 1.0$ acre land, and the household having even no homestead (HS) area or have HS but zero cultivable land (CL) keeps cattle, and their average number per household varied from 1.75 to 2.47 (Figure 1 ).

*Corresponding Author: kshuque58@gmail.com
It was reported that the production of 1.0 ton liquid milk by rural farmers and marketing after processing may support at least 30.0 rural farm families (Huque 2006). Dairy farming supports more than $50 \%$ of the annual income of farmers irrespective of their sex or land ownership, and on average daily 0.85 litre milk is available for family consumption. Thus, smallholder dairy supports family income, nutrition and women empowerment (Table 1).

\section{Production system of dairy cattle}

The smallholder dairy production systems in Bangladesh being integrated with crop agriculture may be classified into rural, peri-urban and structured market dairy (The Country Report of 
Bangladesh 2005). A summary of different attributes of the three dairy production systems based on survey researches conducted by the Bangladesh Livestock Research Institute (BLRI) (Huque et al. 2002) in some selected areas of Bangladesh during 2001 to 2002 are described below.

\section{Rural dairy production system}

Most of the land poor farmers under rural dairy keep cattle and $61.1 \%$ of the respondent farmers had less than 2.49 acres of total land (Figure 2), and they were categorized again into landless having $\leq 0.49$ acres, marginal having $\leq 0.99$ acres and small having $\leq 2.49$ acres of total land. The rest $38.9 \%$ of the total respondents keep cattle were medium having 7.49 acres and large farmers having $\geq 7.50$ acres of land. The landless, marginal, small, medium or a large farmer of the selected regions having an average total land of $0.3,0.7,1.40,3.10$ and 11.70 acres/farm, respectively keeps average $1.20,1.70,1.20,1.90$ and 2.30 milking cows, respectively and produces daily $3.90,4.20,3.70,7.80$ and 8.20 Litres of milk, respectively (Table 2 ). I rrespective of land categories and region, a rural dairy farmer kept 5.69 cattle of $2.41: 1$ local to crossbreds, produces 5.56 litres milk daily with a benefit to cost ratio of 1.78: 1 . About $62.8 \%$ of their annual income depends on the dairy.

Table 1. Annual income, women empowerment and nutrition impact of dairying

\begin{tabular}{lllll}
\hline \multirow{2}{*}{ Farmers } & Milking & \multicolumn{2}{l}{ Annual income (\%) } & Availability of \\
\cline { 3 - 4 } & Cows/ & Dairy & Other & milk/day/family \\
& Household & farming & sources & (Litre) \\
\hline Female & 3 & 63.3 & 36.7 & 0.50 \\
Male & 1.25 & 47.2 & 52.8 & 0.87 \\
Landless & 2.33 & 65.7 & 34.3 & 0.67 \\
Landholders & 1 & 44.6 & 55.4 & 0.50 \\
All & 2 & 54.6 & 45.4 & 0.85 \\
\hline
\end{tabular}

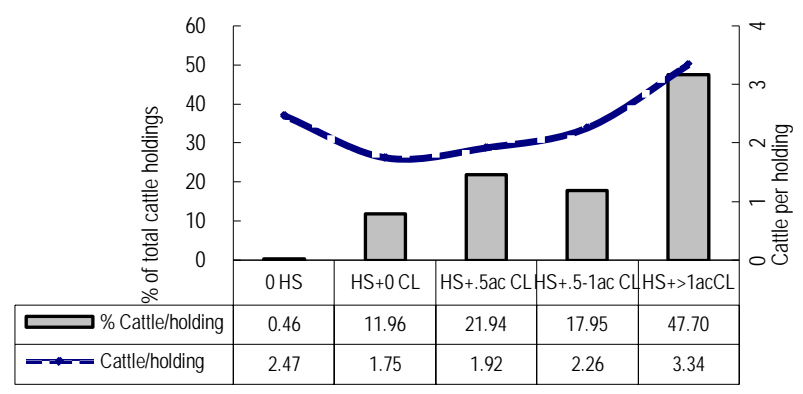

Figure 1. Distribution of cattle per household (Agriculture Census 1996)
The rural dairy farmers fed rice straw, cut and carry green grass and a conventionally mixed concentrate mixture $(50.5 \%$ rice bran, $24.3 \%$ wheat bran, $19.1 \%$ oil cake and $6.10 \%$ broken rice). Irrespective of farm category the average daily allowance per animal of individual feed was $5.17 \pm 0.96 \mathrm{~kg}$ dry rice straw, $5.36 \pm 0.33 \mathrm{~kg}$ cut and carry grass and $1.47 \pm 0.24 \mathrm{~kg}$ concentrate (Table 3).

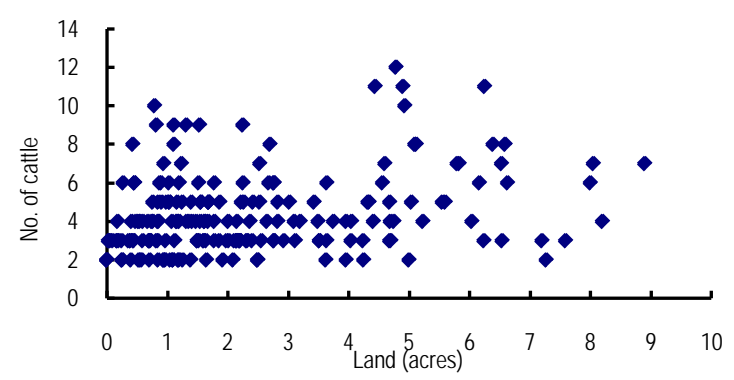

Figure 2. Distribution of rural dairy cattle and land area (Rahman et al. 2002)

About $47.1 \%, 29.1 \%$ and $23.7 \%$ of the dairy farmers feed their animals in stalls, stall cum open or open system, respectively (Table 4). The average daily milk production per cow and days in lactation of local and crossbred cows under the rural dairy system was 2.08 litre and 6.39 litre and 248 and 300 days, respectively. Milking, feeding, cleaning and milk marketing are the major work in dairying, and man and women share $58.7 \%$ and $41.3 \%$, respectively, of the work.

Table 2. Rural dairy farm characteristics based on farmers category (Rahman et al. 2002)

\begin{tabular}{|c|c|c|c|c|c|c|}
\hline \multirow[t]{2}{*}{ Attributes } & \multicolumn{5}{|c|}{ Farm categories under rural dairy } & \multirow{2}{*}{$\begin{array}{l}\text { Daily } \\
\text { allowance/ } \\
\text { animal }\end{array}$} \\
\hline & Landless & Marginal & Small & Medium & Large & \\
\hline $\begin{array}{l}\text { Land size } \\
\text { (acres) }\end{array}$ & 0.3 & 0.7 & 1.40 & 3.10 & 11.70 & 3.44 \\
\hline Total cattle & 4.0 & 5.34 & 4.29 & 6.62 & 8.21 & 5.69 \\
\hline $\begin{array}{l}\text { Ratio of Local } \\
\text { to crossbred }\end{array}$ & 2.05 & 4.31 & 2.54 & 1.93 & 1.21 & 2.41 \\
\hline $\begin{array}{l}\text { Milking cow } \\
\text { (No.) }\end{array}$ & 1.20 & 1.70 & 1.20 & 1.90 & 2.30 & 1.66 \\
\hline $\begin{array}{l}\text { Milk/farm/day, } \\
\text { (Litre) }\end{array}$ & 3.90 & 4.20 & 3.70 & 7.80 & 8.20 & 5.56 \\
\hline $\begin{array}{l}\text { Benefit: Cost } \\
\text { ratio }\end{array}$ & 1.65 & 1.93 & 1.52 & 1.91 & 1.92 & 1.78 \\
\hline $\begin{array}{l}\text { Annual } \\
\text { income from } \\
\text { cattle }(\%)\end{array}$ & 57.5 & 66.0 & 72.8 & 51.5 & 66.3 & 62.8 \\
\hline
\end{tabular}


Table 3. Feeding characteristics under rural dairy (Rahman et al. 2002)

\begin{tabular}{|c|c|c|c|c|c|c|}
\hline \multirow{2}{*}{$\begin{array}{l}\text { Dietary } \\
\text { components }\end{array}$} & \multicolumn{5}{|c|}{ Farm categories under rural dairy } & \multirow[t]{2}{*}{ Average } \\
\hline & Landless & Marginal & Small & Medium & Large & \\
\hline $\begin{array}{l}\text { Rice straw, } \\
\text { (Fresh Kg) }\end{array}$ & 4.76 & 4.18 & 5.81 & 4.58 & 6.51 & 5.17 \\
\hline $\begin{array}{l}\text { Cut and carry } \\
\text { grass }(\mathrm{kg})\end{array}$ & 4.67 & 6.23 & 4.93 & 5.16 & 5.82 & 5.36 \\
\hline $\begin{array}{l}{ }^{*} \text { Concentrate } \\
\text { mixture }(\mathrm{kg})\end{array}$ & 1.12 & 1.49 & 1.64 & 1.37 & 1.74 & 1.47 \\
\hline
\end{tabular}

*Contains $50.5 \%$ rice bran, $24.3 \%$ wheat bran, $19.1 \%$ oil cake and $6.10 \%$ broken rice

Table 4. Characteristics of rural dairy production system (Rahman et al. 2002)

\begin{tabular}{|c|c|c|c|c|c|c|c|c|}
\hline \multicolumn{3}{|c|}{$\begin{array}{l}\text { Production } \\
\text { system (\%) }\end{array}$} & \multicolumn{2}{|c|}{$\begin{array}{c}\text { Gender } \\
\text { share (\%) }\end{array}$} & \multicolumn{2}{|c|}{$\begin{array}{l}\text { Daily milk } \\
\text { (Litre/head) }\end{array}$} & \multicolumn{2}{|c|}{$\begin{array}{l}\text { Days in } \\
\text { lactation }\end{array}$} \\
\hline Stall feed & $\begin{array}{l}\text { Stall+ } \\
\text { Open }\end{array}$ & Open & Men & Women & Local & Crossbred & Local & Crossbred \\
\hline 47.1 & 29.1 & 23.7 & 58.7 & 41.3 & $\begin{array}{c}2.08 \pm \\
0.08\end{array}$ & $\begin{array}{c}6.39 \pm \\
0.49\end{array}$ & $\begin{array}{c}248 \pm \\
6.50\end{array}$ & $\begin{array}{c}300 \pm \\
12.4\end{array}$ \\
\hline
\end{tabular}

\section{Structured market dairy}

The dairies under the structured milk marketing area of the Milk Vita shares $46.0 \%$ of the processed milk in the country, are termed as structured market dairies. Similar to rural dairy, $60.0 \%$ of the farmers was small (landless, marginal and small as described above) and the rest $40.0 \%$ was medium and large farmers. The distribution of cattle owners under the structured market dairy in respect to their land area is shown in Figure 3. It was reported that a landless farmer keeps about 9.21 cattle of $0.34: 1$ local to crossbreds, produce 20.4 litres of milk daily from an average number of 3.44 milking cows, and support $76.2 \%$ of family annual income (Table 5 ).

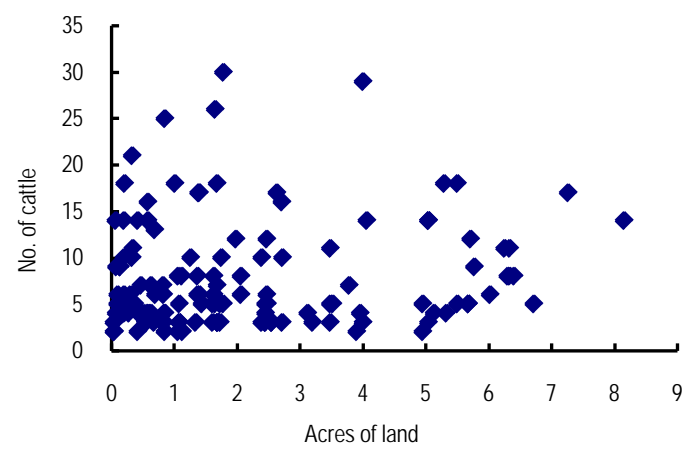

Figure 3. Distribution of dairy herd and land areas (acres) of structured market dairy (Rahman et al. 2002)
The marginal, small, medium and large farmers of the structured marker dairy having an average total land size of $0.68,1.51,3.95$ and 10.20 acres/farm, respectively and produce daily 16.4 , 24.5, 27.1 and 61.9 litre of milk, respectively. Irrespective of land categories a dairy farmer under the structured market dairy keeps 12.2 cattle of 0.53 of milk daily with an average benefit to cost ratio of $1.23: 1$. About $67.5 \%$ of their annual income depends on dairy farming.

Table 5. Characteristics of structured market dairy farm (Huque et al. 2002)

\begin{tabular}{lllllll}
\hline Attributes & \multicolumn{5}{c}{ Farm categories under rural dairy } & \multirow{2}{*}{ Average } \\
\cline { 2 - 6 } & Landless & Marginal & Small & Medium & Large & \\
\hline $\begin{array}{l}\text { Land size } \\
\text { (Acres) }\end{array}$ & 0.21 & 0.68 & 1.51 & 3.95 & 10.2 & 3.31 \\
\hline Total cattle & 9.21 & 6.72 & 9.50 & 10.9 & 24.5 & 12.2 \\
\hline LC ratio & 0.34 & 0.69 & 0.65 & 0.65 & 0.32 & 0.53 \\
\hline Milking cow & 3.44 & 2.71 & 3.06 & 3.65 & 7.96 & 4.17 \\
\hline $\begin{array}{l}\text { Milk/farm/day } \\
\text { (Litre) }\end{array}$ & 20.4 & 16.4 & 24.5 & 27.1 & 61.9 & 30.1 \\
\hline $\begin{array}{l}\text { Benefit: Cost } \\
\text { ratio }\end{array}$ & 1.13 & 1.10 & 1.30 & 1.24 & 1.37 & 1.23 \\
\hline ANI (\%) & 76.2 & 67.0 & 85.6 & 51.3 & 58.8 & 67.8 \\
\hline
\end{tabular}

LC ratio, Local to Crossbred cattle ratio; ANI, annual income from cattle

Except a higher daily allowance of green grass, the average daily dietary composition was almost similar both in respect of type of feed or their daily allowance (Table 6) to that of the rural dairy. The concentrate mixture contains as usually rice or wheat bran, oil cake and broken rice at an average rate of $41.8,35.3,19.5$ and $3.37 \%$, respectively (Huque et al. 2002). I rrespective of farm category the average daily allowance per animal of individual feed was 4.14 $\pm 0.90 \mathrm{~kg}$ dry rice straw, $7.30 \pm 1.73 \mathrm{~kg}$ cut and carry grass and $2.61 \pm 0.36 \mathrm{~kg}$ concentrate (Table 6).

Table 6. Daily allowances of diet $(\mathrm{kg} / \mathrm{head})$ of structured market dairy animals (Huque et al. 2002)

\begin{tabular}{lllllll}
\hline \multirow{2}{*}{$\begin{array}{l}\text { Dietary } \\
\text { components }\end{array}$} & \multicolumn{5}{c}{ Farm categories under rural dairy } & Average \\
\cline { 2 - 6 } & Landless & Marginal & Small & Medium & Large & diet \\
\hline Rice straw & 3.09 & 3.61 & 4.29 & 4.25 & 5.48 & 4.14 \\
Cut and carry & 5.72 & 7.24 & 5.54 & 9.56 & 8.42 & 7.30 \\
grass & & & & & & \\
Concentrate & 2.71 & 2.54 & 2.02 & 2.84 & 2.94 & 2.61 \\
\hline
\end{tabular}


About $51.3,43.3$ and $5.33 \%$ of the dairy farmers feed their animals in stalls, stall cum open or open feeding system, respectively. They are managed both by men and women (54.3 vs $45.7 \%$ ). A trend similar to rural dairy an average daily milk production per cow (3.29 vs 7.88 litres) and days in lactation ( 231 vs 269) of local and crossbred cows irrespective of their rearing system, shown in Table 7.

Table 7. Characteristics of structured market dairy production system

\begin{tabular}{|c|c|c|c|}
\hline $\begin{array}{l}\text { Production } \\
\text { system (\%) }\end{array}$ & $\begin{array}{l}\text { Gender share } \\
\text { in dairying (\%) }\end{array}$ & $\begin{array}{l}\text { Daily milk } \\
\text { Litre/head }\end{array}$ & $\begin{array}{l}\text { Days in } \\
\text { lactation }\end{array}$ \\
\hline $\begin{array}{l}\text { Stall Stall+ Open } \\
\text { feed Open }\end{array}$ & Women & Local CRB & Local CRB \\
\hline $\begin{array}{lll}51.3 & 43.3 & 5.3\end{array}$ & $54.3 \% \quad 45.7 \%$ & $3.29 \pm 2 \quad 7.8$ & $231 \pm 48 \quad 269 \pm$ \\
\hline
\end{tabular}

CRB, crossbred

\section{Peri-urban dairy}

The peri-urban dairy is developed on higher price and demand of milk in urban and peri-urban areas. A similar distribution of land area and cattle number in the peri-urban system was found (Figure 4) to that of the rural or structured market dairy. About $73.7 \%$ of the farmers belonged to small (landless, marginal and small) farm category and the rest $(26.3 \%)$ was medium and large farmers.

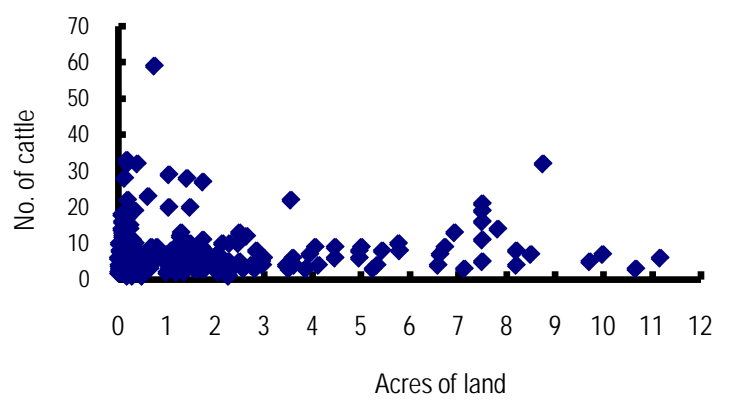

Figure 4. Distribution of peri-urban dairy and land areas (acre) (Rahman et al. 2002)

The land size of the peri-urban and urban dairy farmers has less impact on their dairy keeping compared to other dairy systems. The average land size of five different categories of farmers was $0.17,0.67,1.47,4.22$ and 13.92 acres/farm for landless, marginal, small, medium and large, respectively (Table 8 ). The average number of cattle was $12.4,7.40,8.0,27.2$ and 12.1, respectively including average milking cows of
$4.70,2.30,3.00,7.50$ and 3.20 ; and their daily average milk production was 28.7, 12.7, 20.8, 57.2 and 25.4 litres, respectively. Medium and large farmers had a lower benefit to cost ( 1.01 and 1.02) compared to landless, marginal and small farmers $(1.35,1.32$ and 1.45 , respectively). Large farmers share only $19.0 \%$ of their annual income from dairying, whereas, landless, marginal, small and medium farmers largely depend on dairying for their annual income. Irrespective of land categories, a periurban dairy farmer kept 13.4 cattle of $0.52: 1$ local to crossbreds, produced 28.9 litres of milk daily with an average benefit to cost of $1.23: 1$ (Table 8).

Table 8. Characteristics of peri-urban dairy farmers (Rahman et al. 2002)

\begin{tabular}{lllllll}
\hline \multirow{2}{*}{ Attributes } & \multicolumn{5}{c}{ Farm categories under peri-urban dairy } & \multirow{2}{*}{ Average } \\
\cline { 2 - 6 } & Landless & Marginal & Small & Medium & Large & \\
\hline $\begin{array}{l}\text { Land size } \\
\text { (Acres) }\end{array}$ & 0.17 & 0.67 & 1.47 & 4.22 & 13.92 & 4.01 \\
\hline Total cattle & 12.4 & 7.40 & 8.0 & 27.2 & 12.1 & 13.4 \\
\hline LC ratio & 0.28 & 0.58 & 0.60 & 0.15 & 0.99 & 0.52 \\
\hline $\begin{array}{l}\text { Milking cow } \\
\text { (No.) }\end{array}$ & 4.70 & 2.30 & 3.00 & 7.50 & 3.20 & 4.10 \\
\hline $\begin{array}{l}\text { Milk/farm/day } \\
\text { (Litre) }\end{array}$ & 28.7 & 12.7 & 20.8 & 57.2 & 25.4 & 28.9 \\
\hline $\begin{array}{l}\text { Benefit: Cost } \\
\text { ratio }\end{array}$ & 1.35 & 1.32 & 1.45 & 1.01 & 1.02 & 1.23 \\
\hline ANI (\%) & 52.0 & 43.0 & 71.0 & 79.0 & 19.0 & $53.0 \%$ \\
\hline
\end{tabular}

LC ratio, Local to crossbred cattle ratio; ANI, annual income from cattle

Similar to rural or structured market dairy farmers, the peri-urban dairy farmers fed rice straw, green grass and concentrate mixtures containing rice or wheat bran, oil cake and broken rice at an average mixing proportion of $27.8,30.3, \quad 33.6$ and $7.9 \%$, respectively. Irrespective of farm category, the average daily allowance per animal of individual feed was 5.5 $\pm 1.2 \mathrm{~kg}$ dry rice straw, $4.0 \pm 0.6 \mathrm{~kg}$ cut and carry grass and $2.34 \pm 0.46 \mathrm{~kg}$ concentrate mixture (Table 9).

Table 9. Daily per head diet $(\mathrm{kg})$ of peri-urban dairy animals (Rahman et al. 2002)

\begin{tabular}{|c|c|c|c|c|c|c|}
\hline \multirow[t]{2}{*}{ DC } & \multicolumn{5}{|c|}{ Farm categories under peri-urban dairy } & \multirow{2}{*}{$\begin{array}{l}\text { Average } \\
\text { diet }\end{array}$} \\
\hline & Landless & Marginal & Small & Medium & Large & \\
\hline RS & 4.05 & 5.71 & 4.59 & 6.14 & 7.13 & 5.52 \\
\hline CCG & 3.91 & 3.80 & 3.78 & 5.08 & 3.62 & 4.04 \\
\hline $\mathrm{CM}$ & 2.26 & 1.58 & 2.56 & 2.54 & 2.74 & 2.34 \\
\hline
\end{tabular}

$D C$, dietary components; $R S$, rice straw; CCG, cut and carry grass; $C M$, concentrate mixture 
The peri-urban farmers did not keep their animals in open rearing systems, rather $42.9 \%$ of them keep under stall cum open and $57.1 \%$ rear under stall fed condition. Similar to other production system, peri-urban dairy is managed by both the genders $(69.9 \%$ by male and $30.1 \%$ by female). Crossbred cows yield higher milk daily (7.34 litres/cow) compared to local cattle (2.48 litres/cow), and their average lactation length was 265 days compared to 222 days of local cattle (Table 10).

Table 10. Characteristics of peri-urban dairy production system (Rahman et al. 2002)

\begin{tabular}{|c|c|c|c|}
\hline $\begin{array}{l}\text { Production } \\
\text { system (\%) }\end{array}$ & GSDA (\%) & $\begin{array}{l}\text { Daily milk } \\
\text { litre/head }\end{array}$ & $\begin{array}{l}\text { Days in } \\
\text { lactation }\end{array}$ \\
\hline $\begin{array}{ll}\text { Stall Stall+ } \\
\text { feed Open }\end{array}$ & Men Women & Crossbred & Local Crossbred \\
\hline 57.142 .9 & $69.9 \% \quad 30.1 \%$ & $2.48 \pm 0.6 \quad 7.34 \pm 1.9$ & $222 \pm 18 \quad 265 \pm 34$ \\
\hline
\end{tabular}

GSDA, gender share in dairy activity

\section{Average cost of dairy cattle production}

The average cost of dairy production varies according to production systems and the availability of feeds and fodders. The feed cost varied from 80.6 to $83.1 \%$ of the total variable costs (Table 11). Depreciation on the fixed cost was $14.4 \%$ of the total cost and it varied from 9.0 to $28.3 \%$ in different production system. Including the cost of feed, labour (8.2\%), veterinary and $\mathrm{Al}(4.9 \%)$, and the interest $(5.30 \%)$, the total variable cost varied from $71.7 \%$ of the total cost of dairy production in rural to $94.2 \%$ in the peri-urban system.

Table 11. Cost (\%) of dairy cattle production

\begin{tabular}{lcccc}
\hline Items & \multicolumn{4}{c}{ Dairy production system } \\
\cline { 2 - 5 } & Rural Peri-urban & $\begin{array}{c}\text { Structured } \\
\text { market }\end{array}$ & Average \\
& & \multicolumn{4}{c}{} \\
\hline Depreciation cost (\%) & 28.3 & 5.80 & 9.0 & 14.4 \\
Variable Cost (\%) & 71.7 & 94.2 & 91.0 & 85.6 \\
Feed (\% variable cost) & 80.6 & 83.1 & 81.4 & 81.7 \\
Labour (\% variable cost) & 8.75 & 8.69 & 7.09 & 8.2 \\
Veterinary and Al & 5.93 & 3.45 & 5.29 & 4.9 \\
(\% variable cost) & & & & \\
Interest on variable cost (\%) & 4.76 & 4.76 & 6.23 & 5.3 \\
\hline
\end{tabular}

\section{Production system of dairy Buffaloes}

The buffaloes, apart from sporadic distribution all over the country, are available in a higher concentration in some areas, especially; the availability of pastures favours their concentration. A Buffalo pasture, locally called Bathan, is a common land where the animals are kept for a major period of a year. The Buffalo raised in other than Bathan is termed here as Non-Bathan system.

The Buffalo farmers also keep cattle together, and the average number of the bovine (cattle and Buffalo) per household in different regions varied from 6.49 in the North plain Non-Bathan to 134.8 in the North-East Undulated Bathan area (Table 12). It shows that the South delta and North-East Undulated area had the highest bovines per household.

The share of Buffaloes animals varied from $31.0 \%$ to $63.9 \%$ in the Bathan of the South delta. I rrespective of production system, the average bovines per household varied from 6.49 to 134.8 (average 31.01 ) and buffaloes from 31.0 to $63.9 \%$ (average $52.45 \%$; Jalil et al. 2002). Average percent of adult female or male and Young stock among the study areas varied from 4.84 to $56.8 \%$ with an average of $42.9 \%, 1.93$ to $58.0 \%$ with an average of $12.7 \%$, and 13.8 to $90.3 \%$ with an average of $44.9 \%$, respectively. The lactating and non-lactating cows varied from 22.5 to $73.0 \%$ with an average of 47.8 and $27.0 \%$ to $77.5 \%$ with an average of $45.5 \%$, respectively (Table 12 ).

Most of the buffaloes, irrespective of their sex, are kept for draft purpose; milk or meat is considered as secondary purpose (Figure 5). Draft use often affects their production and reproduction performances.

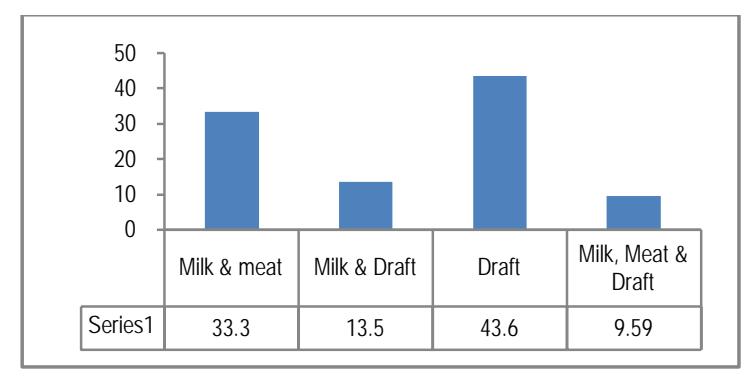

Figure 5. Purposes of buffalo keeping 


\section{A performance profile of Bangladesh dairying}

\section{Registration of dairy farm}

The country has no large scale dairies and all the farms under the three production system are smallholder in nature. The smallholder farmers in the absence of any domestic protection system are reluctant to have their farm registered in the concerned bureau of the government. The Department of Livestock Services (DLS) reported that the number registered dairy farms is 55,174 in different regions, and it calculated to be only about 20 to $25 \%$ of the total dairy farms in the country (personal communication with DLS).

\section{Population and Performances}

\section{Population}

The numbers of cattle and buffaloes according to age, sex reported by BER (2001) is presented in Table 13. The calculated lactating cows varied from 4.08 to 4.14 million out of the total adult female of 9.04 to 9.17 million during 2006 to 2011. The adult female buffalo, on the other hand, was 453 thousand in 2011 including 121 thousand of lactating buffalo cows. Total animal or the number of different age groups increased during the period of 2006 to 2011. Goats are also lactating animals, but local Bengal does, the population of which is around 14.85 million out of total 24.15 million goats in 2011 hardly spare any liquid milk for human consumption, and the most of their milk is used for mothering their multiple kids (Not shown in the Table).

Average herd composition of bovine animals, and per cent bovines reared under subsistence and commercial condition is shown in Figure 6 . It shows that the average number of bovines per household is 2.0, and the same number $(2.0$ bovines per household) is also reported as the average of the subsistence system. The later consists about $99.23 \%$ of the total 25.14 million bovines. Commercial farming, more correctly, the input supported system consists only $0.77 \%$ of the bovines, and an average per household number is 13 (Figure 6). It was estimated that the ratio of bovines to human in the country is 0.18: 1 (BBS 2011).

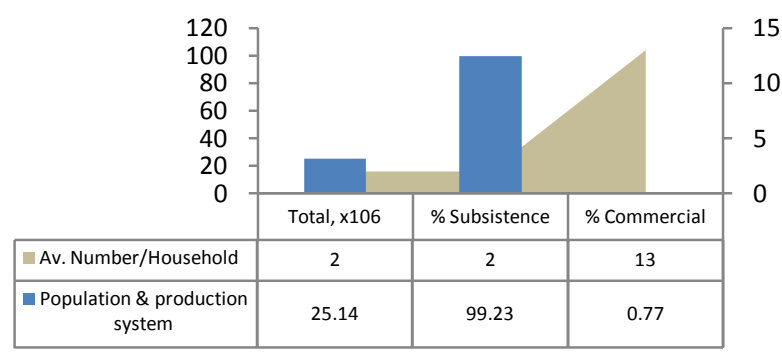

Figure 6. Total bovines, \% farming and average household size (BBS 2011)

\section{Performance}

The productive and reproductive performances of different genotypes of cattle varies according to their rearing conditions, and the regions of the country. The productive and reproductive performances of cattle on-farm or on-station and the performance of two imported cattle breed onstation are presented in Table 14.

It shows that both the production and reproduction performance of different genotypes are better at on-station than that of the on-farm condition. The cows of Red Chittagong Cattle (RCC) having 170 to $190 \mathrm{Kg}$ mature weight and the lowest lactation performance (461 to 675 litres) among the genotypes, is the most efficient animal in respect to post-partum heat period and age of puberty (49 to 64 days and 18.8 to 32.1 months, respectively; Table 14). Considering the economic selection index or total merit compared to other available genotypes, RCC cows were recommended for rural dairy farming in the country (Khan et al. 2012).

Table 12. Bovines per household and Buffalo herd composition under Bathan and Non-bathan system in different buffalo potential area of the country (Jalil et al. 2002)

\begin{tabular}{|c|c|c|c|c|c|c|c|c|c|c|}
\hline \multirow[t]{2}{*}{ Items } & \multicolumn{2}{|c|}{ North Plain } & \multicolumn{2}{|c|}{ Padma-Jamuna floodplain } & \multicolumn{2}{|c|}{ Old Brahmaputra floodplain } & \multicolumn{2}{|c|}{ South delta } & \multicolumn{2}{|c|}{ North East Undulated area } \\
\hline & Bathan & Non-Bathan & Bathan & Non-Bathan & Bathan & Non-Bathan & Bathan & Non-Bathan & Bathan & Non-Bathan \\
\hline $\begin{array}{l}\text { Bovine/ } \\
\text { Household }\end{array}$ & 13.4 & 6.49 & 17.1 & 6.67 & 7.82 & 8.72 & 59.7 & 33.5 & 134.8 & 21.94 \\
\hline \%Buffalo & 46.9 & 45.3 & 62.1 & 31.0 & 57.1 & 44.5 & 62.9 & 63.9 & 53.6 & 57.2 \\
\hline \multicolumn{11}{|c|}{ Herd Composition, \% } \\
\hline Adult Female & 46.4 & 28.3 & 58.1 & 4.84 & 46.2 & 42.4 & 49.5 & 49.1 & 56.8 & 47.6 \\
\hline Lactating & 59.4 & 22.5 & 52.7 & 32.6 & 59.0 & 73.0 & 48.7 & 39.6 & 39.5 & 50.9 \\
\hline Non-lactating & 40.6 & 77.5 & 47.3 & 0 & 41 & 27 & 51.3 & 60.4 & 60.5 & 49.1 \\
\hline Adult Male & 5.8 & 58.0 & 1.93 & 4.84 & 5.63 & 21.1 & 3.05 & 16.8 & 1.66 & 8.02 \\
\hline Young stock & 47.8 & 13.8 & 40.0 & 90.3 & 53.17 & 36.6 & 47.40 & 34.1 & 41.6 & 44.4 \\
\hline
\end{tabular}


Huque (2014) Bang. J. Anim. Sci. 43 (2): $81-103$

Table 13. Bovine population of Bangladesh (BER 2013)

\begin{tabular}{|c|c|c|c|c|c|c|c|c|}
\hline \multirow[t]{2}{*}{ Bovine animals } & \multicolumn{8}{|c|}{ Years } \\
\hline & 2006 & 2007 & 2008 & 2009 & 2010 & 2011 & 2012 & 2013 \\
\hline \multicolumn{9}{|l|}{ (a) $\quad$ Cattlex106 } \\
\hline Total Population (BBS, 2011, BER 2013) & 22.8 & 22.87 & 22.9 & 22.97 & 23.05 & 23.12 & 23.2 & 23.2 \\
\hline Adult male (Calculated) & 8.78 & 8.80 & 8.82 & 8.84 & 8.87 & 8.90 & 8.93 & 8.95 \\
\hline Adult Female (Calculated) & 9.04 & 9.07 & 9.08 & 9.11 & 9.14 & 9.17 & 9.20 & 9.22 \\
\hline Lactating Cows & 4.08 & 4.09 & 4.10 & 4.11 & 4.12 & 4.14 & 4.15 & 4.16 \\
\hline Non-lactating & 4.92 & 4.98 & 4.98 & 5.00 & 5.02 & 5.03 & 5.05 & 5.06 \\
\hline Young stock (Calculated) & 4.97 & 4.99 & 4.99 & 5.01 & 5.02 & 5.04 & 5.06 & 5.17 \\
\hline (b) Buffalox $10^{3}$ & & & & & & & & \\
\hline Total Buffalo; (BBS, 2011) & 1160 & 1210 & 1260 & 1300 & 1350 & 1390 & 1443 & 1447 \\
\hline Adult Male (Calculated) & 675 & 704 & 733 & 757 & 786 & 809 & 840 & 842 \\
\hline Adult Female (Calculated) & 378 & 395 & 411 & 424 & 440 & 453 & 470 & 472 \\
\hline Lactating cows & 102 & 106 & 110 & 114 & 118 & 121 & 126 & 126 \\
\hline Non-lactating & 277 & 289 & 301 & 310 & 322 & 332 & 344 & 345 \\
\hline Young stock (Calculated) & 107 & 111 & 116 & 120 & 124 & 129 & 132 & 133 \\
\hline
\end{tabular}

Having an average mature weight of $281.0 \mathrm{Kg}$, Pabna cows had lactation yield of 918.0 Litres, post-partum heat period of 106 to 150 days and age of puberty of 28.1 to 38.5 months. The Pabna cattle, instead of dairy, was more efficient in beef production, and compared to even Brahma crossbreds with the local, it was more efficient in feed conversions (Roy et al. 2013). Friesian had the highest average lactation yield of 2661.0 litres followed by 1056.0 litres of a Sahiwal cows. Their post-partum heat period and age of puberty was 108 days and 22.0 months and 126 days and 39.1 months, respectively. Similar performances of indigenous cows were 120 days and 32.6 months, respectively, and their lactation yield was 6.53 litres.

\section{Performance of crossbred dairy cattle}

Similar to pure-genotypes; the performance on farm of different crossbreds was lower than that of the on-station (Table 15). It shows that FriesianxSahiwal crossbred was a top milk producer (2239 litres lactation yield) among the assembled genotypes followed by local crosses with Friesian (1956 litres) or with Jersey (1605 litres). However, puberty age was the lowest with JerseyxLocal crosses (16.7 months) at on-station condition. The local crosses with Friesian, Sahiwal or Jersey had 3.67 litres, 3.02 litres and 2.27 litres daily milk yield, respectively; 156 days, 117 days and 239 days post-partum heat period, respectively; and 34.0 months, 33.6 months and 36.7 months age of puberty, respectively at onfarm condition (Table 15).

\section{Herd composition of the three dairy systems and their performance}

The average performance of the three defined dairy production system is further compared with the performance of the dairy of the north plain, a non-defined common production system (Table 16). Under the three defined system, farmers on average kept 10.2 cattle including 5.26 cows, 0.59 bulls, 1.82 growing animal and 2.52 calves. About $54.0 \%$ of the cattle was genetically assembled and $62.0 \%$ of the cows were lactating (Table 16).

Table 14. Productive and reproductive performances of indigenous and purebred dairy cattle (Hossain et al. 2011, Deb et al. 2007)

\begin{tabular}{|l|cc|cc|cc|cc|}
\hline \multirow{2}{*}{ Items } & \multicolumn{2}{|c|}{ Red Chittagong } & \multicolumn{2}{|c|}{ Pabna } & \multicolumn{2}{c|}{ Indigenous } & Friesian & Sahiwal \\
\cline { 2 - 9 } & On-farm & On-station & On-farm & On-station* & On-farm & On-station & On-Station \\
\hline Daily milk yield, (litre/cow) & 2.23 & 2.98 & 3.1 & 3.61 & 2.25 & - & - & - \\
Lactation yield (litre) & 461 & 675 & 763 & 918 & - & 653 & 2661 & 1056 \\
Lactation length (days) & 206 & 226 & 246 & 256 & - & - & - & - \\
Post partum heat period (days) & 64 & 49 & 150 & 106 & 203.0 & 120 & 108 & 126 \\
Service per conception (No.) & 1.53 & 1.22 & 1.50 & 1.70 & 1.76 & 1.76 & 1.27 & 1.90 \\
Age at puberty (months) & 32.1 & 18.8 & 38.5 & 28.1 & 40.8 & 32.6 & 22 & 39.1 \\
\hline
\end{tabular}

*The data of performance in-situ of Pabna cattle is from the area other than Baghabari 
Table 15. Productive and reproductive performances of crossbred cattle (Majid et al. 1995, Roy et al. 2007)

\begin{tabular}{|l|ccc|cc|ccc|}
\hline \multirow{2}{*}{ Items } & \multicolumn{4}{|c|}{ On-Station } & \multicolumn{3}{c|}{ On-Farm } \\
\cline { 2 - 9 } & \multicolumn{3}{|c|}{ Friesian crosses with } & \multicolumn{2}{c|}{ Local Crosses with } & \multicolumn{3}{c|}{ Crosses with } \\
\cline { 2 - 9 } & Local & Pabna & Sahiwal & Sahiwal & Jersey & Friesian & Sahiwal & Jersey \\
\hline Daily milk yield (litre/cow) & - & 5.62 & - & 3.58 & 5.1 & 3.67 & 3.02 & 2.72 \\
Lactation yield (litre) & 1956 & 1644 & 2239 & 933 & 1605 & - & - & - \\
Lactation length (days) & - & 291 & - & 260 & 305 & - & - & - \\
Post partum heat (days) & 117 & 164 & 149 & 137 & 204 & 156 & 117 & 239 \\
Service per conception (No.) & 2.20 & 1.36 & 2.21 & - & - & - & - & - \\
Age at puberty, (months) & 26.3 & - & 25.7 & - & 16.7 & 34.0 & 33.6 & 36.7 \\
\hline
\end{tabular}

The data on non-defined common dairies were collected from Kurigram, Thakurgaon and Sirajganj (other than structured market dairy area) districts of the north plain area of Bangladesh under the project sites of FAO (Table 16). It shows that an average cattle farm keeps 3.52 cattle with 1.79 cows $(50.9 \%)$ consisting $72.0 \%$ lactating cows and $47.0 \%$ crossbreds. It shows that even a common dairy farmer keep $47.0 \%$ crossbred cows (Table 16 ).

Table 16. Average herd composition of dairies of different systems

\begin{tabular}{lcc}
\hline Items & $\begin{array}{c}\text { Average of the three defined } \\
\text { production system }\end{array}$ & $\begin{array}{c}\text { Dairy of north } \\
\text { plain (FAO) }\end{array}$ \\
\hline Total & 10.2 & 3.52 \\
Cows & 5.26 & 1.79 \\
Bulls & 0.59 & 0.31 \\
Growing & 1.82 & 0.32 \\
Calves & 2.52 & 1.10 \\
Lactating (\%) & 62 & 72 \\
Crossbreds (\%) & 54.1 & 47 \\
\hline
\end{tabular}

\section{Production performance of dairies kept on different feed base}

The farmers of Baghabari, one of the milk potential areas of the country under the structured milk marketing system of the BMPCUL, support better feeding and nutrition to their animals. Being a breeding habitat of local potential cattle (locally called Pabna cattle) the farmers use to support better management to their cows also. Nevertheless, the local Pabna cattle was crossed with Friesian or Sahiwal. The crossbreds of the later two breeds were also raised in the system. Das et al. (2003) showed that Pabna or its crosses or the crossbred of
Friesian and Sahiwal reared in the Baghabari area had production and reproduction performances (Table 17) similar to that of their performances found at on-station condition. The performance of LocalxFriesian crosses in a poor feed base (Baset 2013), on the other, (Lactation yield 1402 litres, Table 17) was poorer than that of its performance at on-station condition (Lactation yield 1956 litres; Table 15). At a poor feed base the average daily milk yield $(\mathrm{Kg})$ of the local cow was 2.97 litre and that of the crossbred cow was 6.07 litre; lactation length was 219 and 231 days, respectively; average service per conception was 1.44 and 1.55 times, respectively (Table 17 ).

\section{Performance of dairy Buffalo}

The average puberty age, service per conception, post-partum heat period, and calving interval of Buffalo cows were reported to be 3.03 years, 1.80 times, 66.4 days and 383.3 days, respectively (Table 18 ). The average daily milk production is only 2.80 litres with an average lactation length of 227 days.

\section{Dairy cattle breeding}

Bangladesh, inheriting a succession of cattle breeding program through introduction of Sahiwal, Hariana and Sindhi bulls in preindependence periods since 1915 has been implementing country-wide artificial insemination (AI) programme for dairy development since 1973, when Friesian and Jersey from Australia were newly introduced. Friesian and Sahiwal overriding the use of Sindhi in 1972 and that of Jersey in 1982 occupied almost the whole public sector cattle Al program. But, the use of Jersey semen by the member farmer of the BMPCUL has been continuing since 2000 . 
Huque (2014) Bang. J. Anim. Sci. 43 (2): 81- 103

Table 17. Productive and reproductive performance in different feed bases (Baset et al. 2012)

\begin{tabular}{lcccccc}
\hline \multirow{2}{*}{ Items } & \multicolumn{2}{c}{ Good feed base (Baghabari Bathan) } & \multicolumn{2}{c}{ Poor feed base } \\
\cline { 2 - 6 } & Pabna & Pabna xFriesian & PabnaxSahiwal & FriesianxSahiwal & Local & Friesian crossbreds \\
\hline Daily milk yield, Litre & 4.27 & 8.28 & 6.78 & 10.6 & 2.97 & 6.07 \\
Lactation yield, Litre & 965 & 2070 & 1545.8 & 2756 & 650 & 1402 \\
Lactation length, days & 226 & 250 & 132 & 228 & 260 & 219 \\
Post partum heat, days & 105 & 1.36 & 127 & 145 & - & - \\
Av. Service per conception & 1.29 & 28.1 & 3.37 & 1.43 & 1.44 & - \\
Months of puberty & 38.6 & & 3.7 & 25.2 & - \\
\hline
\end{tabular}

Table 18. Productive and reproductive performance of Buffalo ( $\mathrm{J}$ alil et al. 2002)

\begin{tabular}{lccc}
\hline Performance & \multicolumn{3}{c}{ Production system } \\
\cline { 2 - 4 } & Bathan & Non-Bathan & Average \\
\hline Age at puberty (years) & 3.05 & 3 & 3.03 \\
Service per conception (No.) & 1.85 & 1.75 & 1.8 \\
Post partum heat, (days) & 68 & 64.8 & 66.4 \\
Calving intervals (days) & 388 & 378.5 & 383.3 \\
Average daily milk (litre) & 2.75 & 2.85 & 2.80 \\
Lactation length (days) & 226 & 228 & 227 \\
\hline
\end{tabular}

Some of the local cattle (viz, Red Chittagong, Pabna) in respect to their many economic aspects are potential and a few of them are conserved ex-situ or in situ for protecting their genetic dilutions and for their improvement following the breeding policy of the government (Bhuiyan et al. 2007). The local cows common in nature are used for production of crossbreds with Friesian or Sahiwal bulls. These two purebred cattle were imported in different times in the past, and still, in addition to semen import, some of the existing bulls are being replaced to produce semen.

Table 19. Genotypes of cow in Bangladesh (Sarker et al. 2013)

\begin{tabular}{ll}
\hline Genotypes & Number (x1000) \\
\hline (a) Indigenous & \\
Common local & 3584.0 \\
Red Chittagong Cattle (RCC) & 10 \\
Pabna & 94 \\
Munshigonj & 13 \\
(b) Crossbred & \\
$\quad$ Local x Shahiwal & 331 \\
Local x Friesian & 1659 \\
Local x Shahiwal x Friesian & 221 \\
\hline Total & 6900 \\
\hline
\end{tabular}

The DLS recently showed that the country till 2010 had 6900 thousand of productive cows and heifers of different genotypes (Table 19), of which 2211 thousand (32.0\%) are reported to be crossbreds of various assembled genotypes. It does not support the claim of extending Al services to $66.1 \%$ adult female of the country by the DLS. Nevertheless, this differs with the estimated adult female cattle population of 9220 thousands and the average per cent of assembled genotypes $(47.0 \%$ in the north plain area or average $54.1 \%$ in the three dairy production system) (Table 16).

The DLS produces and extends semen of purebred bull of Friesian, Sahiwal, and Red Chittagong Cattle, and that of the first cross FriesianxSahiwal or LocalxFriesian bulls. The Central Al laboratory of the DLS has 190 bulls of different genotypes (Table 20), and has a target to have 325 bulls to produce 4800 thousand dosages of semen by 2021. In addition to the central lab, one regional lab, 22 district $\mathrm{Al}$ centres and $1059 \mathrm{Al}$ sub-centres and points comprised a country-wide Al-network to implement the Al activities. Some of the areas remain out of its reach, and a few of them is served by the BRAC through its $70 \mathrm{Al}$ points covering 101 milk collection centres in different districts. The BRAC serves about 46000 farmers and the BMPCUL, including marketing support, provides Al services to 99,144 members of 2025 primary societies in its 32 milk shed areas of the country. Other private Al services are very limited both in number and areas.

Table 20. Bulls available at the central Al laboratory of the DLS in the year 2010

\begin{tabular}{lll}
\hline Genotypes & Breed/Crossbred & Number \\
\hline Exotic & Friesian & 10 \\
& Sahiwal & 10 \\
\multirow{2}{*}{ Indigenous } & Red Chittagong Cattle & 2 \\
& Common local & 6 \\
Crossbred & Local x Friesian & 162 \\
\hline Total & & 190 \\
\hline
\end{tabular}


Various types of genetically assembled cattle are available in different region of the country (Table 21). Friesian is the most preferred exotic breed used to produce crossbreds followed by Sahiwal or sporadically combinations of the two breeds with the indigenous are also available. Nevertheless, in the absence of strict recording system the blood composition of the cattle was not reported. Both experts and farmers favoured adoption of a long term strategy for selection and grading up of the best performing local breeds and follows it up with exotic blood at a later stage (Jabbar et al. 2010). The authors found no support to the current casual and haphazard approach to continue crossbreeding with exotic animals. Expressing a strong preference for dairy breed development, field expert and farmers, as respondents to the research team, echoed a slogan of "more milk from a cow". However, the authors gave almost an equal weight to the exotic breeds and native cattle available in the country, and emphasized to have structured programme on dairy breed development.

Table 21. Availability of on-farm crossbred cattle (Majid et al. 1998)

\begin{tabular}{|c|c|c|c|}
\hline \multicolumn{4}{|c|}{ Areas } \\
\hline West plain & $\begin{array}{l}\text { North-East } \\
\text { Undulated }\end{array}$ & $\begin{array}{l}\text { Padma-Jamuna } \\
\text { floodplain }\end{array}$ & North plain \\
\hline$\overline{\mathrm{LO} \times \mathrm{FR}}$ & LOxFR & LOxFR & $\overline{L O x F R}$ \\
\hline SLxFR & $\begin{array}{l}\text { SLXFR } \\
\text { LOxSLXFR }\end{array}$ & $\begin{array}{l}\text { SLxFR } \\
L O \times S L \times F R \\
S N \times S L \times F R\end{array}$ & $\begin{array}{l}\text { SLXFR } \\
L O \times S L \times F R\end{array}$ \\
\hline
\end{tabular}

LO, Local; FR, Friesian; SL, Sahiwal; SN, Sindhi

\section{Systems of cattle breeding}

Rural, peri-urban or structured dairy farmers use $\mathrm{Al}$, natural or both the systems for breeding their cows. With a variation of $31.8 \%$ in the rural to $57.6 \%$ in peri-urban system about $44.9 \%$ of the farmers used $\mathrm{Al}$, followed by $38.9 \%$ natural and $16.2 \%$ both natural and Al. A higher number of farmers of peri-urban or structured market dairy used $\mathrm{Al}$ (57.6\% and $45.2 \%$ ) compared to other systems (Table 22). Majid et al. (1998) reported that $46.4 \%$ of the farmer used $\mathrm{Al}$ followed by $21.3 \%$ and $32.4 \%$ who practiced natural or both $\mathrm{Al}$ and natural system.
Table 22. Methods of breeding cows followed in different system

\begin{tabular}{lccc}
\hline \multirow{2}{*}{$\begin{array}{l}\text { Production } \\
\text { system }\end{array}$} & \multicolumn{3}{c}{ Breeding methods (\% Respondents) } \\
\cline { 2 - 4 } & Artificial Insemination & Natural & Both \\
\hline Rural & 31.8 & 56.8 & 11.4 \\
Peri-urban & 57.6 & 32.5 & 9.96 \\
Str. Market & 45.2 & 27.4 & 27.4 \\
Average & 44.9 & 38.9 & 16.2 \\
\hline
\end{tabular}

However, the public sector has been implementing breed up-gradation through progeny test and development of $\mathrm{Al}$ and embryo transfer activities to achieve the goal by 2021 .

\section{Systems buffalo breeding}

Buffalo development programme through Al using imported semen of Mediterranean buffalo is also being implemented by the DLS since 2009 following the breeding policy of the country. Besides, a private company named Lal Teer Ltd. also initiated crossbreeding programme for dairy Buffalo development in the country.

\section{Feed dynamics and plane of nutrition}

\section{Feed dynamics}

The bovine animal in the country are mostly raised on fibrous crop-residues and cereal mill by-products. The total roughage production in the country was estimated to be $51056 \times 10^{3}$ ton in 2012 , of which $5781 \times 10^{3}$ ton comes from cut and carry and road side grazing (Huque and Sarker 2013). The green grass availability, however, varies according to regions, seasons, and most importantly with dairy production system. About $27316.4 \times 10^{3}$ ton $(53.5 \%)$ of the fibrous biomass produced in the country is available to animals as feed and the rest of the bulk is gone off and used otherwise. Cereal milling by-products, grains and oilcakes are the three major feed ingredients constitute concentrate feed in the country. About $2042.0 \times 10^{3}$ ton of corn is used annually mainly for commercial poultry and it covers $40.6 \%$ of the total concentrate feeds. Total cereal mill byproducts is $2915.9 \times 10^{3}$ ton ( $58.0 \%$ ) and they are used both for ruminants and poultry, and the rest is oilcakes from different oil seed mill shared both by the two groups of animals (Table 23). The country produces around $72.0 \times 10^{3}$ ton of molasses every year, and most of it is exported and used for ethanol production locally. 
Huque (2014) Bang. J. Anim. Sci. 43 (2): 81- 103

Table 23. Dynamics of feeds and fodder and their annual production (BBS 2011; BER 2013)

\begin{tabular}{|c|c|c|c|c|c|c|c|c|}
\hline \multirow{2}{*}{ Crops } & \multirow{2}{*}{$\begin{array}{l}\text { Cereal yield } \\
\left(\times 10^{3} \text { ton/year) }\right.\end{array}$} & \multicolumn{4}{|c|}{ Fibrous crop residue production (x103 ton) } & \multicolumn{3}{|c|}{ Cereal or its by-products (x103 ton) } \\
\hline & & Types & Fresh & Dry matter & Availability & Types & Production & Availability \\
\hline 1 & 2 & 3 & 4 & 5 & 6 & 7 & 8 & 9 \\
\hline Rice & 34430 & Straw & 44759 & 40283 & $20142(50 \%)$ & Bran & 2754 & 2754 \\
\hline Maize & 2042 & Stover & 4084 & 2042 & $204(10 \%)$ & $\begin{array}{l}\text { Corn } \\
\text { Bran }\end{array}$ & $\begin{array}{l}2042 \\
163.4\end{array}$ & $\begin{array}{l}2042 \\
N / A^{*}\end{array}$ \\
\hline Wheat & 1036 & Straw & 1036 & 932 & $9.32(10 \%)$ & Bran & 82.9 & 82.9 \\
\hline Minor cereals & 0.97 & Straw & 3.80 & 3.49 & - & - & - & - \\
\hline Pulses & 232 & Offal & 928 & 835 & $835(100 \%)$ & Bran & 6.96 & 6.96 \\
\hline Sesame & 31.0 & - & - & - & - & Oilcake & 25.1 & 25.1 \\
\hline Rape and Mustard & 246 & - & - & - & - & Oilcake & 18.2 & 18.2 \\
\hline Ground nut & 54.0 & - & - & - & - & Oilcake & 14.8 & 14.8 \\
\hline Coconut & 326 & - & - & - & - & Oilcake & 2.93 & 2.93 \\
\hline Cotton & 5.90 & - & - & - & - & Oilcake & 7.27 & 6.54 \\
\hline Sugarcane & 4670 & $\begin{array}{c}\text { Tops } \\
\text { Leaves }\end{array}$ & $\begin{array}{l}934 \\
467\end{array}$ & $\begin{array}{l}373 \\
210\end{array}$ & $\begin{array}{l}74.6(20 \%) \\
210(100 \%)\end{array}$ & Molasses & 72.0 & - \\
\hline Potato & 8326 & Plants & 1665 & 499 & $49.9(10 \%)$ & - & - & - \\
\hline $\begin{array}{l}\text { Mango, pineapple, banana and } \\
\text { jackfruits }\end{array}$ & 2871 & Waste & 631 & 93.8 & 9.38 & - & - & - \\
\hline Mulberry & 14.0 & Leaves & 1.40 & 0.56 & 0.27 & - & - & - \\
\hline Vegetable & 10516 & Waste & 2629 & 2.63 & 0.65 & - & - & - \\
\hline $\begin{array}{l}\text { Green grasses } \\
\text { (Daily@1kg/head }\end{array}$ & - & $\begin{array}{l}\text { Green } \\
\text { fodder }\end{array}$ & 19272 & 5782 & 5781 & - & - & - \\
\hline Total production & & & & 51056 & 27316 & - & 5118 & 5025 \\
\hline
\end{tabular}

Not available- N/A*

\section{Common plane of nutrition}

The country requires 73800.0 million $\mathrm{Kg}$ total dry matter (DM) annually to feed existing ruminant animals. An average ruminant diet sharing roughage and concentrate DM at a ratio of $2: 1$ will make a total demand of $49200 \times 10^{3}$ and $24608 \times 10^{3}$ ton, respectively. The total annual roughage DM production is $51056 \times 10^{3}$ ton surpassing by $3.77 \%$ of its total annual demand. The loss of roughage results in a deficit of $44.6 \%$ of its demand (Table 24).

Table 24. Demand and availability of dry matter (DM) of feeds and fodder for the ruminants of Bangladesh (Huque and Sarker 2013)

\begin{tabular}{lccc}
\hline \multicolumn{1}{c}{ Items } & Total & Roughage & Concentrate \\
\hline Demand (million kg DM) & 73800 & 49200 & 24608 \\
Production (million kg DM) & 56081.5 & 51056.1 & 5025.4 \\
Deficit (\% of demand) & -20.3 & 3.77 & -79.8 \\
Available (million Kg DM) & 32342 & 27280 & 4953.4 \\
Availability (\%) & 57.7 & 53.4 & 98.6 \\
Deficit, \% of demand) & $56.2 \%$ & $44.6 \%$ & $79.9 \%$ \\
\hline
\end{tabular}

DM, dry matter
The most important factor is the miss-match of production and supply of the biomass. Most of the fibrous residues is produced in the monsoon, when sun drying, the lone system for preservation of crop residues, is difficult and farmers fail to make them available for their animals in dry season. Collection, processing and preservation of fibrous crop residues and their value addition may increase their availability to animals.

The demand and supply situation of concentrate feeds is very poor in the country. About $20 \%$ of the total demand is met by the domestic production of $5025 \times 10^{3}$ ton. The required dietary concentration of metabolizable energy (MJ $\mathrm{ME} / \mathrm{kgDM}$ ) and digestible crude protein (DCP, $\% \mathrm{DM})$ of ruminants varies due mainly to age, sex, physiological stage and production. An average mixed diet for ruminant animals other than calves may contain 7.5 to $11.0 \mathrm{MJ} \mathrm{ME} / \mathrm{Kg} \mathrm{DM}$ and 3.5 to $11.0 \%$ DCP. The total demand of MJME and DCP was calculated following the Livestock Feeding Standard of Bangladesh Standard and Testing Institute (BSTI 2008), and it was compared with their requirement for the ruminant animals available in the country (Table 25). 


\section{A performance profile of Bangladesh dairying}

Table 25. Demand, production and availability of nutrients (Huque and Sarker 2013)

\begin{tabular}{lcc}
\hline Items & Million MJME/year & Million $\mathrm{kg}$ DCP/year \\
\hline Demand & 457265 & 3332 \\
Production & 397224.8 & 959.8 \\
Production deficit (\%) & -13.13 & -71.2 \\
Availability & 250217 & 748.9 \\
Availability (\% of production) & 63.0 & 78 \\
Availability (\% of demand) & 54.7 & 22.5 \\
\hline
\end{tabular}

$M J$, mega joule; $M E$, metabolizable energy; $D C P$, digestible crude protein

The total annual demand of MJME and DCP for the existing ruminant animals is calculated to be 457265 and 3332 million $\mathrm{kg}$, respectively, and the production of the two is 397224.8 million MJME and 959.8 million $\mathrm{kg} \mathrm{DCP}$, respectively. This shows production deficit of is $-13.13 \%$ and $71.2 \%$, respectively. The estimated availability to farmers shows that the animals avail about 250217 million MJME and 748.9 million $\mathrm{kg}$ DCP annually. The availability is calculated to be 63 and $78 \%$, respectively of the production, and 54.7 and $22.5 \%$, respectively of their demand (Table 25).

Table 26. Composition of different diets (Huque and Sarker 2013)

\begin{tabular}{lccc}
\hline Items & Common diet & $\begin{array}{c}\text { Diet of feed } \\
\text { produced }\end{array}$ & $\begin{array}{c}\text { Diet of feed } \\
\text { available }\end{array}$ \\
\hline MJME/kg DM & 6.20 & 6.75 & 7.74 \\
$\mathrm{DCP}(\%)$ & 4.51 & 1.63 & 2.32 \\
\hline
\end{tabular}

$D M$, dry matter; $D C P$, digestible crude protein, $M E$, metabolizable energy

The plane of nutrition on which the ruminant animals are raised is reflected further by the calculated average diet using the feed produced or the feed available to animals (Table 26). Compared to a common diet (a diet containing 6.2 MJ ME/ $\mathrm{kgDM}$ and $4.51 \% \mathrm{DCP}$ ) for all the farm animals of the country irrespective of their physiological conditions and productions, an average diet of feed produced contains 6.75 MJ ME/KgDM and $1.63 \%$ DCP or an average diet of feed available to animals contains 7.74 MJ ME/KgDM and 2.32\% DCP (Table 26).

The feed availability data shows that about $89 \%$ of the roughage produced or available is fibrous crop residues that contain negligible amount (average $2 \%, \mathrm{FAO}$ ) of DCP and the rest $11 \%$ is green biomass. The concentrate production or availability, on the other hand, is far below than the requirement of farm animals, and its deficit is $79.8 \%$ compared to its demand. Similarly, DCP production deficiency is $-71.2 \%$, and only $22.5 \%$ of the demand is available (Table 25).

\section{Fodder Cultivation}

Fodder cultivation, especially in Rabi season, is a conventional practice in the country, and many of the areas lost the practice due to change in cropping system. Kheshari (Lathyrus sativus) and Mashkali (Vigna Mongu) are the traditional legume fodder use to be cultivated in Rabi season after receding of flood water. High yielding fodder cultivation, like Napier, Sweet Jumbo etc., a recent farm practice is being developed in different regions of the country with gradual transformation of subsistence keeping of dairy animals into input supported system (Huque and I slam 2006). Green fodders are also being sold in different local markets, and the farmers of certain places sporadically grow Napier and market it to livestock farmers.

\section{Animal Health and Veterinary Services}

\section{Animal health Problems}

Foot and mouth disease (FMD), anthrax, hemorrhagic septicemia (HS), dystokia, abortion, Diarrhoea, bloat, black quarter (BQ) and mastitis are the major health problems of the dairy cattle (Figure 7). Most of the farmers reported that FMD and bloat are the major problems followed by diarrhoea and mastitis. Dystokia and abortion are the least prevalent problems among the three systems. Mastitis, compared to structured or peri-urban system is less prevalent diseases in rural production system (Rahman et al. 2002).

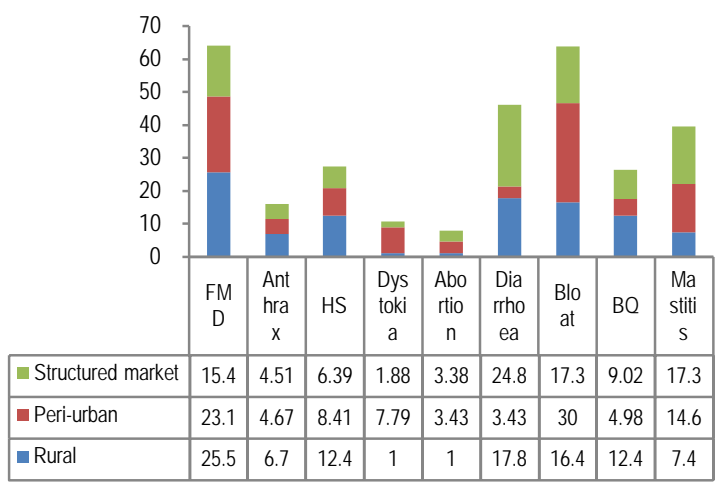

Figure 7. Comparative disease problem (\% respondent); FMD, foot and mouth disease; HS, hemorrhagic septicaemia.; $B Q$, black quarter 
Most of the animals are died of FMD, anthrax, dystokia, diarrhoea, bloat or BQ (Figure 8). Anthrax and BQ are the cause of death of most of the animals in the rural dairies, and diarrhoea, on the other hand, is the major cause of death in the structured market area. In addition to diarrhoea, bloat or dystokia are the major causes of death in the peri-urban dairies. The calves are most susceptible to diseases compared to the growing or adult animals (Figure 9).

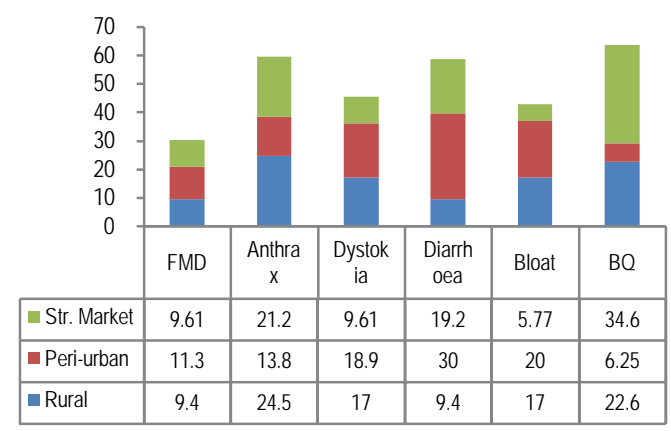

Figure 8. Health problems cause death (\%); FMD, foot and mouth disease; HS, hemorrhagic septicaemia, $B Q$, black quarter

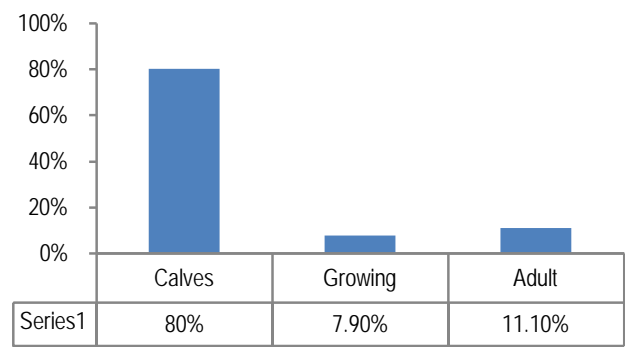

Figure 9. Age group susceptibility (\%) to disease

April to September is hot, humid and rainy period of the year and the rest of the months (November to March) are cooler, less humid, and minimum rain keeps the period dry. The dairy farmers reported that most of the health problem (72.0\%) occurs during April to September (Figure 10).

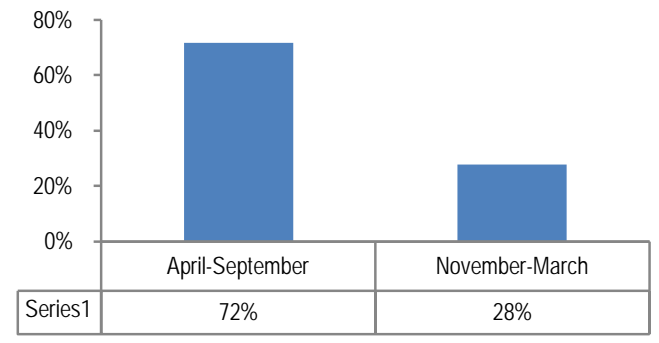

Figure 10. Seasonal variations of disease prevalence

\section{Veterinary Services}

The animal health support is mostly given by the public sector and the major of them includes i) limited preventive health services, ii) disease diagnostic services through a laboratory network at district, regional and central level, and iii) treatment support. Most of the farmers of the three systems use anthelmentics against endoparasites (68.2 to $83.7 \%)$ and vaccinate ( 51.1 to $75.8 \%$ ) their animals (Figure 11 ). Rural farmers had the lowest preventive measures compared to others, and a higher number $(32.6 \%)$ of them take the help of quack veterinary doctor to treat their animals. Structured market or peri-urban dairy production system are better supported in terms of veterinary services $(72.4 \%$ and $86.3 \%$ of the farmer, respectively receive veterinary support) compared to rural dairies.

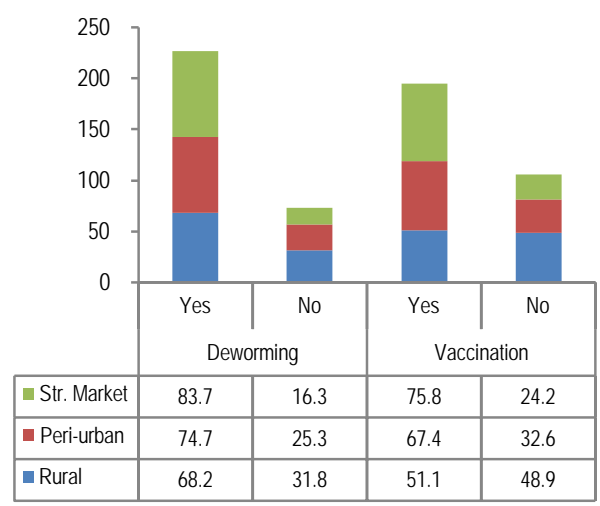

Figure 11. Preventive veterinary services (\% respondent)

\section{Housing and waste management}

Dairy farmers of different production systems use locally available plant materials (Straw, Bamboo, etc) metal ( $\mathrm{Cl}$ sheet, iron bars etc.), and/or concrete materials for the construction of dairy houses. Plant materials were used by $39.9 \%$, 44.2 and $13.6 \%$ farmers (average $32.6 \%$ ) of the rural, peri-urban and structured market dairy, respectively, and the use of metal and concrete materials were higher $(60.1,55.8$ and $86.4 \%$, respectively; average $67.4 \%$, Table 27 ) than the plant materials. Majority farmers of the three system $(59.8 \%)$ dispose dung and other refusal to pits for further use and the rest $(40.2 \%)$ use them otherwise (as fuel and others). Biogas plant was a very new concept during the early 2000 s, and a very negligible $(0.98 \%)$ per cent of farmer 


\section{A performance profile of Bangladesh dairying}

had Biogas plants. The support of different public and private organizations to have Biogas digesters at farm levels may have increased its number recently (Table 27 ).

Table 27. Housing system and waste management (\% respondents; Rahman et al. 2002)

\begin{tabular}{|l|cc|cc|cc|}
\hline \multirow{2}{*}{$\begin{array}{l}\text { Production } \\
\text { system }\end{array}$} & \multicolumn{2}{|c|}{$\begin{array}{c}\text { Construction materials } \\
(\%)\end{array}$} & \multicolumn{2}{|c|}{$\begin{array}{c}\text { Cow dung } \\
\text { pits (\%) }\end{array}$} & \multicolumn{2}{|c|}{$\begin{array}{c}\text { Biogas pit } \\
(\%)\end{array}$} \\
\cline { 2 - 7 } & Plant & Metal and & Pres & Abse & Pres & Abse \\
material & concrete & ent & nce & ent & nce \\
\hline Rural & 39.9 & 60.1 & 78.5 & 21.5 & 1.35 & 98.65 \\
Peri-urban & 44.2 & 55.8 & 54.7 & 45.3 & 0.90 & 99.1 \\
Str. Market & 13.6 & 86.4 & 46.3 & 53.7 & 0.70 & 99.3 \\
Average & 32.6 & 67.4 & 59.8 & 40.2 & 0.98 & 99.02 \\
\hline
\end{tabular}

\section{Milk Production and Projections}

The total milk production in the country is 3.46 million ton in 2013 (Figure 12), and it increased inconsistently during the present decade (BBS, 2011). During the period of 2006 to 2011, the country annually imported $97.0 \times 100$ ton of skim milk powder (SMP), and this is equivalent to $272 \times 1000$ ton of liquid milk. The data on total milk production (Figure 12) without being classified into domestic liquid milk production or imported as SMP is recorded as annual production.

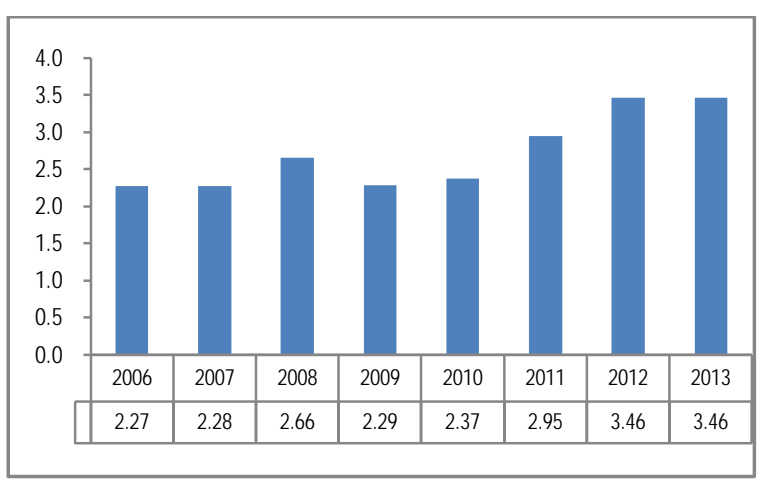

Figure 12. Total liquid milk production, Million tons (BBS 2011; BER 2013)

The Household Income and Expenditure Survey (HIES 2010), however, showed the consumption of liquid milk, the liquid milk equivalent to total consumption of different types of milk products or imported as SMP in 2011. The consumption of milk as liquid, product or SMP was $934 \times 1000$ tons, $934 \times 1000$ tons and $272 \times 1000$ tons, respectively in 2011. This showed that the total annual consumption of milk in the country in 2011 was reported as 2.14 million tons including 0.272 million ton of liquid milk equivalent to imported powder milk. The trend of consumption of liquid milk or product equivalent liquid milk has been increasing slowly but consistently since $1996 / 97$. The import of SMP having a drop in $1994 / 95$ to $2002 / 03$ has been increasing again during the past few years (Table 28).

Table 28. Consumption of liquid milk, liquid milk equivalent product or imported milk ( $\times 1000$ ton) (BBS 2011)

\begin{tabular}{cccc}
\hline Year & $\begin{array}{c}\text { Product } \\
\text { equivalent to } \\
\text { liquid milk }\end{array}$ & Liquid milk & $\begin{array}{c}\text { SMP } \\
\text { equivalent to } \\
\text { liquid milk }\end{array}$ \\
\hline $1980-81$ & 571 & 556 & 92 \\
$1982-83$ & 603 & 603 & 116 \\
$1984-85$ & 362 & 362 & 264 \\
$1986-87$ & 371 & 371 & 284 \\
$1988-89$ & 379 & 379 & 304 \\
$1990-91$ & 381 & 381 & 240 \\
$1992-93$ & 395 & 395 & 152 \\
$1994-95$ & 532 & 532 & 80 \\
$1996-97$ & 776 & 776 & 104 \\
$1998-99$ & 797 & 797 & 96 \\
$2000-01$ & 818 & 818 & 124 \\
$2002-03$ & 840 & 840 & 97 \\
$2004-05$ & 862 & 862 & 228 \\
$2006-07$ & 885 & 885 & 152 \\
$2008-09$ & 909 & 909 & 296 \\
$2010-11$ & 934 & 934 & 272 \\
\hline
\end{tabular}

The retail price (US\$/Litre) of liquid milk in the present decade has also been increasing and having a price drop during 2005 to 2008, it is being increased linearly in the recent years. The retail price of liquid milk was US\$ 0.48 per Litre in 2003, reduced to US\$0.33 in 2006, and it increased again at US\$0.77.

\section{Trend in consumption of milk products}

The consumption of indigenous products increased consistently during the last decades, and it reaches at 139.0 tons in 2011 (Table 29). The use of Chana, a coagulated milk solid based sweet, Ghee or the total curd increased at a higher rate than that of the others. 
Table 29. Trend in production of milk products (BBS 2011)

\begin{tabular}{ccccccc}
\hline Year & \multicolumn{5}{c}{ Milk products } & $\begin{array}{c}\text { Total } \\
\text { milk }\end{array}$ \\
\cline { 2 - 6 } & Ghee & Chana & Butter & Cheese & $\begin{array}{c}\text { Total } \\
\text { curd }\end{array}$ & products \\
\hline $1980-81$ & 19 & 22 & 1 & 1 & 22 & 65 \\
$1982-83$ & 21 & 24 & 1 & 1 & 24 & 71 \\
$1984-85$ & 12 & 14 & 1 & 1 & 14 & 42 \\
$1986-87$ & 13 & 15 & 1 & 1 & 15 & 45 \\
$1988-89$ & 13 & 15 & 1 & 1 & 15 & 45 \\
$1990-91$ & 13 & 15 & 1 & 1 & 15 & 45 \\
$1992-93$ & 13 & 15 & 1 & 1 & 15 & 45 \\
$1994-95$ & 18 & 24 & 1 & 1 & 21 & 65 \\
$1996-97$ & 27 & 31 & 1 & 1 & 27 & 87 \\
$1998-99$ & 27 & 31 & 1 & 1 & 27 & 87 \\
$2000-01$ & 28 & 32 & 1 & 1 & 28 & 90 \\
$2002-03$ & 29 & 33 & 1 & 1 & 29 & 93 \\
$2004-05$ & 30 & 35 & 1 & 1 & 30 & 97 \\
$2006-07$ & 62 & 35 & 1 & 1 & 31 & 130 \\
$2008-09$ & 63 & 36 & 1 & 1 & 32 & 133 \\
$2010-11$ & 65 & 38 & 1 & 1 & 34 & 139 \\
\hline
\end{tabular}

\section{Projection of Milk Production}

Considering the total liquid milk production of 3.46 million ton in 2012 (BER 2013), the estimated per capita annual intake of liquid milk is estimated to be 21.4 litre $(23.6 \%$ of the requirement). Extrapolation of the data shows that the predicted total milk production and its per capita consumption will be 4.91 million ton and $27.5 \mathrm{Kg}$, respectively in 2021 (Figure 13). It calculates to be only $30.0 \%$ of the requirement of a person (91.0 Litre/person/year). The annual per capita availability of milk will remain below than that of the average $(55.0 \mathrm{Kg} / \mathrm{head}$ in 2015 or $67 \mathrm{~kg}$ in 2030; Steinfeld et al. 2006) of the developing country. This trend of production may not support quality nutrition to $85 \%$ of the people by 2021 as the government envisaged.

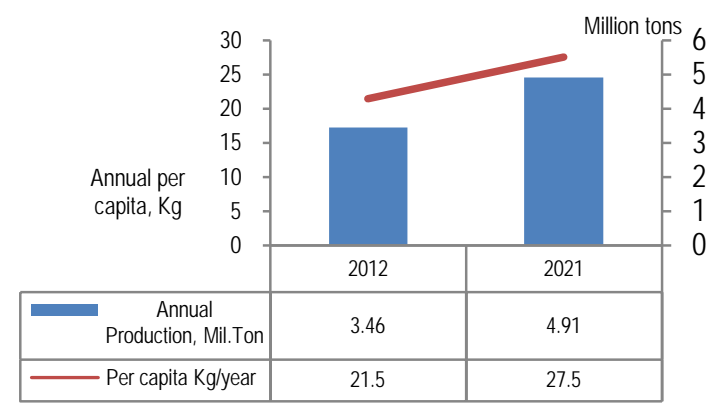

Figure 13. Total and per capita milk production and projection

\section{Data delusion and estimation of production and demand}

The total liquid milk consumption in the country was 1.87 million tons (except the import, BBS 2011), while the same document without specifying domestic production or the amount of import showed that the total liquid milk production in the country was 2.95 million tons in 2011. The data of producing 3.46 million ton of liquid milk in 2012 (BER, 2013) further results in a surplus production of 1.32 million tons of milk. The country, on the other hand having supply of only $23.6 \%$ of the total annual requirement in 2012, imports about 0.272 million ton of SMP equivalent liquid milk.

The population of the country is about 160 millions in 2012, and, if the present growth rate does not decline over time, it will reach at 178.5 millions in 2021. Moreover, $1 \%$ of the cultivable land has been disappearing every year. This has been narrowing down the scope of horizontal expansion of dairy. The growth of population, urbanization and literacy will further boost milk demand in the domestic market in future. Considering these demand conditions of milk and milk products, the domestic competitive advantages of dairy enterprises requires to be improved having support of both the public and private sectors. The present production, demand and supply condition of milk and milk products required to be analyzed further and based on that a strategic planning for meeting growing demand in changing and challenging socio-economic condition is required to be formulated.

\section{Estimated milk production}

The country has 4.16 million lactating cows (Table 13), and $47.0 \%$ of them estimated to be crossbreds (Table 22). This estimates total local and crossbred lactating cows of 2.20 and 1.96 million, respectively. The lactating buffalo is 0.126 million (Table 13).

The average daily milk yield (litre) and lactation length (days) of local and crossbred cows were 2.68 and 230 and 6.91 and 266, respectively. A Buffalo cow, on the other hand, yields about 2.80 Litre daily in an average lactation period of 227 days (Table 18). This calculates lactation yield of 618.7 Litre/local cow, 1838.0 Litre/Crossbred cow and 635.6 Litre/buffalo cow (Table 30). 
Table 30. Production performances and total milk yield in the country

\begin{tabular}{lccccc}
\hline $\begin{array}{l}\text { Types of } \\
\text { Bovines }\end{array}$ & $\begin{array}{c}\text { Daily milk } \\
\text { yield } \\
\text { (Litre/cow) }\end{array}$ & $\begin{array}{c}\text { Lactation } \\
\text { length } \\
\text { (days) }\end{array}$ & $\begin{array}{c}\text { Lactation } \\
\text { yield } \\
\text { (Litre) }\end{array}$ & $\begin{array}{c}\text { Lactating } \\
\text { cows } \\
\text { (millions) }\end{array}$ & $\begin{array}{c}\text { Liquid } \\
\text { milk } \\
\text { (tons) }\end{array}$ \\
\hline Local cow & 2.69 & 230.0 & 618.7 & 2.20 & 1.36 \\
Crossbreds & 6.91 & 266 & 1838.0 & 1.96 & 3.60 \\
Buffalo cows & 2.80 & 227 & 635.6 & 0.126 & 0.08 \\
\hline Total annual milk production & & & 5.04 \\
\hline
\end{tabular}

Multiplying the lactation yield by the total lactating cows results in the annual liquid milk production of $1.36,3.60$ and 0.08 million tons, respectively, from the three genotypes (Table 29). This leads to an estimated annual total liquid milk production of 5.04 million tons. The cattle produce $98.4 \%$ (4.96 million tons) of the total liquid milk, and the rest $(1.60 \%)$ is produced by buffalo cows (Table 29).

\section{Marketing of milk and milk products}

\section{Marketing of milk}

Liquid milk, and milk products and powder milk of imported or domestic origins are being marketed through different systems. Liquid milk produced by farmers is marketed i) traditionally in local markets directly by the producers, ii) through middlemen (Milkmen and Wholesaler), iii) to structured marketing organizations like, the BMPCUL or iv) to product manufacturers (Figure 14). About $54.0 \%, 52.3 \%$ and $37.0 \%$ farmers under rural, peri-urban and structured dairy, respectively sell their milk in the local market (Figure 15).

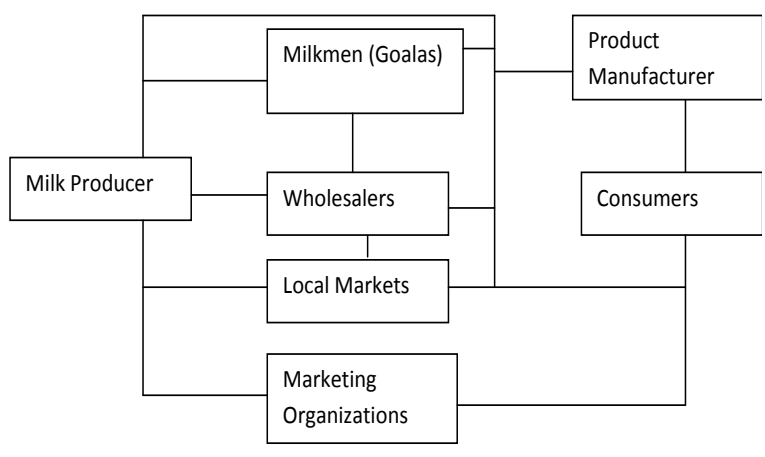

Figure 14: Milk marketing system of Bangladesh

The price of milk in the local market except that in the peri-urban and urban areas fluctuates even up to $50 \%$, while milk demand gyrates depending on socio-economic factors. Farmers of certain areas, instead of selling milk individually in local market, sell their daily milk in a group of 10 to 12 farmers to the nearby towns or cities to fetch a better price, and each member of the group is rotationally responsible for milk marketing. This is locally called "Pali system" and it ensures better market price and safes working hours of the farmers. Middlemen, on the other hand, procure milk from $34,39.2$ and $16 \%$ farmers of rural, peri-urban and structured dairy areas, respectively. Middlemen exploit dairy producers both by low price (up to $40 \%$ lower than market price) and by taking higher milk weight (up to $25 \%$ additional weight of Litre). They, trusting enhanced shelf life and/or reduced bumpy milk, use leaves of Banana, Date Palm and Bamboo or Water hyacinth in their milk containers during transportation. They also use water, dried chille or mustard oil as organic preservatives and $\mathrm{H}_{2} \mathrm{O}_{2}$, $\mathrm{NaHCO}_{3}$ or even Formalin as chemical prservative to increase shelf life of liquid milk during marketing.

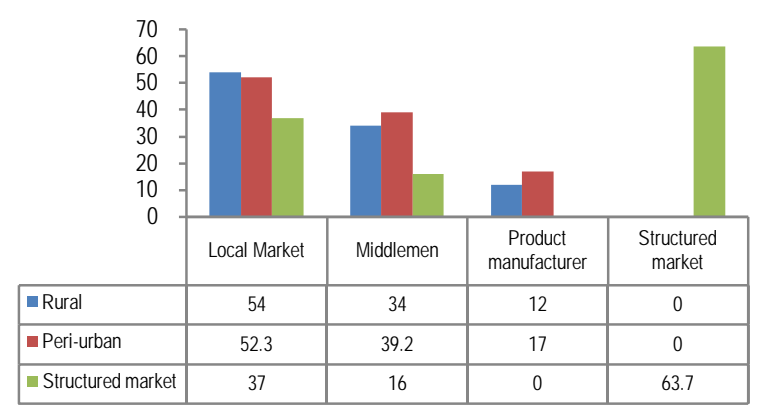

Figure 15. Milk marketing share (\%) by different system (Roy et al. 2002)

\section{Composition of milk}

Animal genotypes, dietary composition, seasons and other physiological factors affect milk composition. The milk of RCC had the highest percent of fat, protein, solid not fat (SNF) or total solid than that of local Pabna or FriesianxLocal cows $(5.29,4.11,10.9$ or 16.2 , respectively of RCC; $4.91,3.93,10.4$ or 15.31 , respectively of Pabna; and 4.11, 3.71, 9.85 and 13.96, respectively of FriesianxLocal cow; Table 30). The milk composition of RCC was similar to that of Jersey $(5.50,3.90,9.50$ and 15.0 , respectively. Lactose $(5.91,6.19$ and 5.33, respectively) or mineral $(0.69,0.72$ and 0.84 , respectively) content of milk of the three genotypes were almost similar (Table 31). 
Huque (2014) Bang. J. Anim. Sci. 43 (2): 81- 103

Table 31. Composition of milk of different genotypes reared on-station or onfarm (Baset 2010)

\begin{tabular}{|c|c|c|c|c|c|}
\hline \multirow{2}{*}{$\begin{array}{l}\text { Quality of } \\
\text { milk (\%) }\end{array}$} & \multicolumn{2}{|c|}{ Local (On-station) } & \multicolumn{2}{|c|}{ Friesian×Local } & \multirow[t]{2}{*}{ Average } \\
\hline & $\mathrm{RCC}$ & Pabna & On-station & On-farm & \\
\hline Fat & 5.29 & 4.91 & 4.47 & 3.74 & 4.11 \\
\hline Protein & 4.11 & 3.93 & 3.71 & 3.71 & 3.71 \\
\hline Lactose & 5.91 & 6.19 & 5.35 & 5.30 & 5.33 \\
\hline Minerals & 0.69 & 0.72 & 0.89 & 0.78 & 0.84 \\
\hline SNF & 10.9 & 10.4 & 9.86 & 9.83 & 9.85 \\
\hline Total Solid & 16.19 & 15.31 & 14.33 & 13.57 & 13.96 \\
\hline
\end{tabular}

RCC, Red Chittagong cattle, SNF, solids-not-fat

Baset et al. (2013) collected milk samples from farmers of different regions with a difference in quality of diets, and reported that except fat percent ( 3.95 vs $3.73 \%$ ), other milk components were similar both for local or crossbred cows raised on similar dietary conditions (Table 32). But, the milk of cows reared on good quality diets had a higher level of fat, protein, lactose, SNF, minerals and total solid $(3.96,3.79,5.49,10.09$, 0.63 and $14.06 \%$, respectively) compared to that raised on poor quality diets $(3.73,3.63,5.29$, $9.80,0.61$ and $13.52 \%$, respectively).

Table 32. Composition of milk of different genotypes on feed base or seasons (Baset et al. 2013)

\begin{tabular}{lcccc}
\hline \multirow{2}{*}{\begin{tabular}{l} 
Milk components \\
\multicolumn{1}{c}{$(\%)$}
\end{tabular}} & \multicolumn{2}{c}{ Genotypes } & \multicolumn{2}{c}{ Feed base } \\
\cline { 2 - 5 } & Local & Crossbreds & Good & Poor \\
\hline Fat & 3.95 & 3.73 & 3.96 & 3.73 \\
Protein & 3.73 & 3.70 & 3.79 & 3.63 \\
Lactose & 5.40 & 5.38 & 5.49 & 5.29 \\
SNF & 9.40 & 9.89 & 10.09 & 9.80 \\
Minerals & 0.61 & 0.63 & 0.63 & 0.61 \\
Total solids & 13.95 & 13.63 & 14.06 & 13.52 \\
\hline
\end{tabular}

SNF, Soilds not fat

The milk sample collected from the chilling centre of the milk marketing organization had 3.75, $3.29,4.71,8.70$ and $12.45 \%$ fat, protein, lactose, SNF or total solid, respectively (Table $32)$. But, a low quality $(3.51,3.19,4.62,8.52$ and $12.03 \%$, respectively) was reported by Sarker et al. 2013, who collected milk sample from the middlemen of the same area. Similarly, the milk of middlemen from north or central plain area had SNF or fat\% lower than the standard composition of milk (Table 33).

Table 33. Composition of milk sample collected from Middlemen and a chilling centre

\begin{tabular}{lcccc}
\hline $\begin{array}{l}\text { Milk } \\
\text { components } \\
(\%)\end{array}$ & \multicolumn{3}{c}{ Middlemen } & $\begin{array}{l}\text { Chilling } \\
\text { Centre }\end{array}$ \\
\cline { 2 - 5 } & $\begin{array}{l}\text { North } \\
\text { plains }\end{array}$ & $\begin{array}{c}\text { Central } \\
\text { plains }\end{array}$ & $\begin{array}{c}\text { Padma- } \\
\text { Jamuna } \\
\text { floodplain }\end{array}$ & $\begin{array}{c}\text { Padma- } \\
\text { Jamuna } \\
\text { floodplain }\end{array}$ \\
\hline Fat & 3.57 & 3.32 & 3.51 & 3.75 \\
Protein & 2.96 & 2.96 & 3.19 & 3.29 \\
Lactose & 4.25 & 4.25 & 4.62 & 4.71 \\
SNF & 7.83 & 7.83 & 8.52 & 8.7 \\
Total Solid & 11.40 & 11.15 & 12.03 & 12.45 \\
\hline
\end{tabular}

SNF, Solids-not-fat

\section{Marketing of Processed Milk}

The BMPCUL, a pioneering public shared dairy marketing organization established in 1973 under the Rural Development and Cooperatives Division (RDCD) of the Govt. of the People's Republic of Bangladesh, shares $46.0 \%$ of the total processed milk in the country. The rest $54.0 \%$ of the processed milk is marketed by dairy marketing organizations of the private sector, and they, without following cooperative principles, collect liquid milk through establishing chilling centres in different dairy potential areas and market it after processing. The Dairy and Food project of BRAC in the brand name of Arong, established in 1988, markets about 97000 litres of milk daily and share $25 \%$ of the total processed milk. The Pran Dairy Ltd. sharing $15.3 \%$ markets about 60000.0 litres of liquid milk in the brand name of Pran Milk. The Akij Dairy Itd. started their dairy marketing business in 2007 in the name of Fresh Milk and daily markets about 24000.0 litres of milk (6.14\%). Abdul Momen Ltd in the brand name of Amo Milk, Shilaidaha Dairy Ltd., Aftab Dairy Ltd., Rangpur Dairy Ltd., Baro-Awolia Dairy Ltd. are some of the private dairy entrepreneurs marketed 1 to $2 \%$ of the total processed milk in the country (Table 34).

It may be calculated that only about $7.64 \%$ of the total liquid milk produced locally is processed and marketed through structured marketing system of the country. 
Table 34. Milk marketing organizations of Bangladesh (Mandal 2013)

\begin{tabular}{|c|c|c|c|c|c|}
\hline $\begin{array}{l}\text { Sl. } \\
\text { No }\end{array}$ & Entrepreneurs & Brand & $\begin{array}{c}\text { Year of } \\
\text { establish- } \\
\text { ment }\end{array}$ & $\begin{array}{l}\text { Daily } \\
\text { Milk } \\
\text { (Litre) }\end{array}$ & $\begin{array}{c}\text { Market } \\
\text { Share } \\
(\%)\end{array}$ \\
\hline 01. & BMPCUL & Milk Vita & 1973 & 180000 & 46 \\
\hline 02. & BRAC & Aurong & 1988 & 97000 & 25 \\
\hline 03. & Pran Dairy & Pran Milk & 2001 & 60000 & 15.3 \\
\hline 04 & Akij Dairy & Akij Milk & 2007 & 24000 & 6.14 \\
\hline 05. & Abdul Monem & Amo Milk & 1996 & 6000 & 1.5 \\
\hline 06 & $\begin{array}{l}\text { Shilaidaha } \\
\text { Dairy }\end{array}$ & Ultra Milk & 1998 & 4000 & 1 \\
\hline 07 & Aftab Dairy & Aftab Milk & 1998 & 6000 & 1.5 \\
\hline 08 & Rangpur Dairy & RD Milk & 2007 & 8000 & 2.04 \\
\hline 09 & Military Farm & Army Milk & 1988 & 2000 & 0.5 \\
\hline 10 & $\begin{array}{l}\text { Baro-Awolia } \\
\text { Dairy }\end{array}$ & $\begin{array}{l}\text { Pabna } \\
\text { Milk }\end{array}$ & 2011 & 4000 & 1 \\
\hline Total & & & & 391000 & 100 \\
\hline
\end{tabular}

The composition of processed and marketed milk of different marketing organizations is shown in Table 35. Some of the organizations market a lower quality milk (BM- 6 and MLM-1) in respect to standard fat content (as low as $3.28 \%$ ) keeping their SNF\% even higher than the level approved by the BSTI. Sometimes sugar and other adulterants are used to maintain national standard during marketing of adulterated milk.

Table 35. Composition of milk of different marketing organization (Sarker et al. 2013)

\begin{tabular}{lcccc}
\hline Brand Milk & Fat\% & Protein\% & Lactose\% & SNF\% \\
\hline BM-1 & 3.53 & 3.59 & 5.21 & 9.57 \\
BM-2 & 3.58 & 3.41 & 4.96 & 9.10 \\
BM-3.1 & 3.60 & 3.35 & 4.88 & 8.95 \\
BM-4 & 3.53 & 3.45 & 5.05 & 9.24 \\
BM-5 & 3.61 & 3.42 & 4.98 & 9.13 \\
BM-6 & 3.40 & 3.54 & 5.15 & 9.45 \\
MLM-1 & 3.28 & 3.38 & 4.91 & 9.01 \\
\hline
\end{tabular}

$B M$, brand milk; MLM, market liquid milk.

\section{Biological quality of milk}

The biological quality in terms of total viable or Coliform count ( $\mathrm{cfu} / \mathrm{ml}$ milk) of milk is presented in Table 36. It shows that the viable count of the brand milk sample varied from 30.0 to $0.35 \times 10^{6}$ and all of them were within the maximum permitted level approved by the FDA Pasteurized milk ordinance (2009). BM-3.2 brand UHT milk had no Coliform, and the lowest count of BM-2 pasteurized milk sample (15 cfu/ml) was even above the maximum permissible level $(10 / \mathrm{ml})$. The other pasteurized milk samples including BM4 UHT milk exceeded the maximum permissible level. All the milk samples collected from the middlemen of different areas had a total viable or Coliform count more than the fresh liquid milk of Grade A (contains total bacteria $<50,000 / \mathrm{ml}$ ) or Grade-B $(50,000$ to $200,000 / \mathrm{ml})$, and boiling is the only option to get rid of this huge bacterial load in market liquid milk.

Table 36. Bacteriological analysis of milk (Sarker et al. 2013)

\begin{tabular}{|c|c|c|c|c|}
\hline \multirow[t]{2}{*}{ Source } & \multirow[t]{2}{*}{$\begin{array}{l}\text { Brand/ } \\
\text { Source }\end{array}$} & \multirow[t]{2}{*}{ Types } & \multicolumn{2}{|c|}{$\begin{array}{l}\text { Bacteriological load } \\
\text { (cfu/ml of milk) }\end{array}$} \\
\hline & & & $\begin{array}{l}\text { Total Viable } \\
\text { Count }\end{array}$ & $\begin{array}{l}\text { Total } \\
\text { Coliform }\end{array}$ \\
\hline Coded & BM-1 & Pasteurized & $0.25 \times 10^{6}$ & 200,000 \\
\hline \multirow[t]{4}{*}{ Brand Milk } & BM-2 & Pasteurized & 30 & 15 \\
\hline & BM-3.1 & Pasteurized & $0.0083 \times 10^{6}$ & 4200 \\
\hline & BM-3.2 & UHT & $0.35 \times 10^{6}$ & 0 \\
\hline & BM-4 & UHT & 460 & 70 \\
\hline $\begin{array}{l}\text { Market } \\
\text { Liquid milk }\end{array}$ & MLM-1 & $\begin{array}{l}\text { Liquid milk } \\
\text { (Packed) }\end{array}$ & $1.5 \times 10^{12}$ & $3 \times 10^{11}$ \\
\hline \multirow[t]{6}{*}{ (Middlemen) } & Chittagong & Liquid milk & $2.35 \times 10^{12}$ & $3.25 \times 10^{11}$ \\
\hline & Gazipur & Liquid milk & $7.6 \times 10^{6}$ & $4.45 \times 10^{5}$ \\
\hline & Savar & Liquid milk & $4.9 \times 10^{8}$ & - \\
\hline & Dhaka & Liquid milk & $4.39 \times 10^{9}$ & $4.53 \times 10^{7}$ \\
\hline & Pabna & Liquid milk & $1.17 \times 10^{9}$ & $5.08 \times 10^{11}$ \\
\hline & Sirajganj & Liquid milk & $9.0 \times 10^{11}$ & $5.2 \times 10^{11}$ \\
\hline
\end{tabular}

$B M$, brand milk; MLM, market liquid milk

\section{Indigenous milk products}

Bangladesh uses about $50.0 \%$ of its liquid milk for the production of different types of products (934×1000 tons, BBS 2011) listed in Table 36. Locally called Rashogolla, Chomchom, Rasomalai, Kalojam, Sandesh, Chomchom, Dahi, Danadar, Rashkadam, Malaikari etc. are available in different regions of the country. Some of the milk products (Muktagacha-Manda of the Old Brahmaputra, Bogra-Dahi of the North plain, Comilla-Roshomalai of Eastern undulating, Austagram-Cheese of Surma-Meghna floddplain etc have typical specific taste and flavor in some regions. Manufacturing of indigenous products from 1 ton of liquid milk may create average employment of 28.0 man days (Roy et al. 2002), and an estimated 72644 persons are employed in the dairy cottage industries of in the country. 
Table 37. Indigenous dairy products (Roy et al. 2002)

\begin{tabular}{ll}
\hline \multicolumn{1}{c}{ Dairy zones } & \multicolumn{1}{c}{ Milk products } \\
\hline North plains & Spong-Rashagolla, Pera-Sandesh, \\
& Dudhia-Sandesh, Katari-Bhog, Raj- \\
& Bhog, Chhanamurki, Maya-Bhog, \\
& Pranhara, Khirkadam, Postodana, \\
& Mauya, Raghobsoi,Manda-Sandesh, \\
& Dammisri, Khirsha, Aubak-Sandesh \\
& Pera Raghobsoi, Khirmon, Kanchagolla \\
& and Panitoa. \\
Old Brahmaputra floodplain & Manda, Chhana-Polau \\
Eastern undulating areas & Chhana-Murki, Roshomalai, Pera, \\
& Chhana-Jilapi, Lalmohon and Malaikari \\
Surma-Meghna floodplains & $\begin{array}{l}\text { Austagram-Cheese, Pera, Katari-Bhog, } \\
\text { Mawchak, Balish }\end{array}$ \\
& Shorpuria, Chhana-Polau, Spong- \\
South delta & Roshogolla, Pera, Raj-Bhog, Chhana- \\
& Jilapi, Kamla-Bhog, Khirpuri \\
Padma-Jamuna floodplains & Raghobsoi, Raj-Bhog, Katari- Bhog, \\
& Chhana-Jilapi, Panitoa-Ghol, Lalmohon \\
\hline
\end{tabular}

\section{Milk products marketing organization}

Some of the dairy entrepreneurs, other than indigenous products, produce various types of milk products using domestic liquid milk and some of them use imported powder milk. A list of dairy entrepreneurs with the name and estimated annual production of their products are presented in Table 38. It shows that seventeen different entrepreneurs annually produce about 177837.3 tons of different types of milk products including powder and flavoured milk, Ice Cream, Butter, Butter oil, Curd (Dahi), Condensed milk and Cheese. Their calculated annual production is $585,642,19475,1004,865,1865,153300$, and 102 ton, respectively. Most of the condensed milk is produced from the imported powder milk. Butter oil is the common item produced both by indigenous manufacturers and dairy entrepreneurs.

\section{Dairy development programs}

\section{Dairy Production and Extension}

The DLS, a public sector extension organization, has been implementing Al programmes for genetic development of dairy cattle in the country since 1973. Recently, it has been jointly implementing smallholder dairy development programme, a regional initiative of FAO since 2010. Dairy marketing programmes, such as i) Milk cooperative society extension and ii) Development of cooperative based milk production sustainably projects, on the other hand, are being implemented by the RDCD since 2009.
Table 38. Milk product marketing by different entrepreneur (Mandal 2013)

\begin{tabular}{|c|c|c|c|c|c|c|c|c|}
\hline \multirow[t]{2}{*}{ Entrepreneur } & \multicolumn{8}{|c|}{ Annual production of different milk products (Tons) } \\
\hline & $\begin{array}{c}\text { Powder } \\
\text { milk }\end{array}$ & $\begin{array}{c}\text { Flavored } \\
\text { milk }\end{array}$ & $\begin{array}{c}\text { Ice } \\
\text { cream }\end{array}$ & Butter & Ghee & $\begin{array}{l}\text { Curd } \\
\text { (Dahi) }\end{array}$ & $\begin{array}{c}\text { Cond. } \\
\text { milk }\end{array}$ & $\begin{array}{l}\text { Che- } \\
\text { ese }\end{array}$ \\
\hline BMPCUL & 385 & - & 2190 & 730 & 548 & 292 & - & - \\
\hline BRAC Dairy & 175 & 548 & - & 274 & 237 & 861 & - & - \\
\hline Pran dairy & 24.5 & - & - & - & - & 128 & - & - \\
\hline Akij dairy & - & 21 & - & - & 73 & 183 & - & - \\
\hline Aftab Dairy & - & 73 & - & - & 7.30 & - & - & - \\
\hline $\begin{array}{l}\text { Abdul } \\
\text { Momen }\end{array}$ & - & - & 1225 & - & - & 183 & - & - \\
\hline $\begin{array}{l}\text { Dhaka Ice } \\
\text { Cream }\end{array}$ & - & - & 9125 & - & - & - & - & - \\
\hline $\begin{array}{l}\text { Savoy Ice } \\
\text { Cream }\end{array}$ & - & - & 1095 & - & - & - & - & - \\
\hline $\begin{array}{l}\text { Kawality Ice } \\
\text { Cream }\end{array}$ & - & - & 4380 & - & - & - & - & - \\
\hline $\begin{array}{l}\text { Kazi Food } \\
\text { Industries }\end{array}$ & - & - & 1460 & - & - & - & - & - \\
\hline $\begin{array}{l}\text { Grameen } \\
\text { Danon }\end{array}$ & - & - & - & - & - & 219 & - & - \\
\hline $\begin{array}{l}\text { Danish } \\
\text { Cond. Milk }\end{array}$ & - & - & - & - & - & - & 54750 & - \\
\hline $\begin{array}{l}\text { Starship } \\
\text { Cond. Milk }\end{array}$ & - & - & - & - & - & - & 54750 & - \\
\hline $\begin{array}{l}\text { Tasnim } \\
\text { Cond. Milk }\end{array}$ & - & - & - & - & - & - & 43800 & - \\
\hline $\begin{array}{l}\text { Classic Dairy } \\
\text { Food Prod. }\end{array}$ & - & - & - & - & - & - & - & 14.6 \\
\hline Had’s Man & - & - & - & - & - & - & - & 14.6 \\
\hline Ejab Gr. & - & - & - & - & - & - & - & 73 \\
\hline $\begin{array}{l}\text { Annual } \\
\text { Total }\end{array}$ & 585 & 642 & 19475 & 1004 & 865 & 1865 & 153300 & 102 \\
\hline
\end{tabular}

Cond. milk, condensed milk; BMPCUL, Bangladesh Milk producers Cooperative Union Ltd.

The Bangladesh Agricultural University (BAU) using research grants of the USDA and IAEA developed a Community-based Dairy Veterinary Foundation (CDVF), a non-profit but market driven initiative of veterinarians and dairy farmers and it has been delivering productivity veterinary services to smallholder dairy farmers through organizing them in association in some selected areas of the country.

\section{Milk marketing}

In addition to BMPCUL, a dozen of private marketing organization annually market about $142.7 \times 1000$ tons (391×365 days) of liquid milk (Mandal 2013). All these dairy entrepreneurs, instead of getting any domestic support of the public support, have to compete with the marketing of imported powder milk. Creation of enabling environment for dairy development and coordination of private and public sector activities through passing a coordinating body following the NLDP (2007) may help further development of 


\section{A performance profile of Bangladesh dairying}

dairy industry in the country. Moreover, strengthening dairy value chains integrating social safety and development issues, like that of school milk feeding programme, diversification of production and processing technologies may be the major programmes under Public-PrivatePartnership to address food security, rural employment and income generation, and women empowerment of the country.

\section{Dairy Research}

The Bangladesh Livestock Research Institute (BLRI) initiated development program on RCC conservation ex situ and improvement in 2001, and their conservation in situ and community improvement in their habitats in 2006. The research programme of BLRI showed that the rearing of RCC is profitable in rural dairy production system (Khan et al. 2010). The programme being implemented by periodic funds under the development activity of the government, was ended in June 2011, and considering RCC, a potential dairy cattle, the institute has been continuing the conservation ex situ programme. The BAU, Mymensingh, also implemented RCC conservation and improvement programme financed by the USDA, and the programme is being continued through multiplication of the animal in the area other than the breeding habitats of RCC. The BLRI also initiated Pabna local cattle conservation ex situ programme in 1988, till to date the herd, entitled as BCB-1, is improved into native beef cattle. Feeds and fodder development, a core research and development (RandD) programme of the institute, is being implemented to provide technological supports to dairy farmers.

However, the prevailing research environment has limitations to support a market driven dairy through integrated approaches of both public and private sectors. Most of the researches related to dairy are ended in producing reports, publications, and have limited visions on the development of dairy-business in the country. Limitations on competitive advantages in human factors and RandD policies have been ending with activities without generating knowledge based dairy business in the country. Moreover, scientist access to infrastructural facilities for experimental development of system, prototypes, models, limitations of existing public rules and regulations to deliver paid services to private sector by a public sector scientist, reluctance of private sector to invest in RandD are a few of the factors that are not conducive to development of animal resources.

\section{Dairy Education}

The BAU, Mymensingh offers post-graduation and PhD degree in Dairy Science. The Bachelor of Animal Husbandry degree offered by the Faculty of Animal Husbandry of the BAU, Mymensingh covers 31 credits on dairy sciences out of the total 196. Recently the Science and Technology University, Patuakhali started offering Bachelor degree in Animal Husbandry consisting of a similar course layout on dairy sciences followed by the BAU, Mymensingh. A limited course on dairy science is also included in the Bachelor degree on Veterinary sciences offered by the Chittagong Veterinary and Animal Science University, Sylhet Agricultural University, Haji Danesh Science and Technology University, Dinajpur; Rajshahi University, Sher-e-Bangla Agricultural University, Dhaka; and Bangabandhu Sheikh Mujibur Rahman Agricultural University, Gazipur. Including the BAU, Mymensingh none of the universities or colleges offers any exclusive diploma or bachelor degree on dairy sciences in the country. A very sporadic farmers training programme on dairying is offered by the BLRI, DLS and other related organizations.

\section{Dairy Policies}

\section{Public Sector Policies}

The Ministry of Fisheries and Livestock (MoFL) of the government of the People's Republic of Bangladesh coordinates and monitors livestock development activities through DLS and BLRI. Both the organizations have limited capacity to support dairy development in the country. Private sector plays major roles on dairy production and marketing, a techno-based economy links fork users with farmers. The capacity of the public sector for strengthening smallholder dairy industry through partnership building between the public and private sector is weak and disjointed. Mandates for dairy production rests on the organizations of the MoFL, but marketing and quality regulations are coordinated by different Ministries. The government approved different policies and regulations of the MoFL to support livestock development including dairying in the country. They are listed below.

a) Final draft of National Livestock Extension Policy-2013 with a vision of becoming selfreliant to satisfy the national demand of milk, meat and eggs for fast growing populace 
through increased productivity, thereby accelerating economic growth, employment and income generation and reducing poverty.

b) Animal Slaughter and Meat Quality Control Act-2011

c) Animal Feed Act- 2010

d) Animal Disease Act-2005

e) Bangladesh Animal and Animal Product Quarantine Act-2005 and

f) National Livestock Development Policy-2007

\section{National livestock development policy}

The government of the People's Republic of Bangladesh approved National Livestock Development Policy (NLDP) in 2007. It also documented policies for dairy development in the country and these are i) expansion of cooperative dairy in potential areas following the BMPCUL Model, ii) replication of pro-poor models for community based smallholder dairy, iii) promotion of integrated dairy farming, iii) strengthening of forward linkages to dairy farmers, iv) establishment of a National Dairy Development Board to promote dairy and $v$ ) National Dairy Research Institute to strengthen dairy research and development activities. Moreover, encouraging private sector's participation, establishment of farmers information network taking help of the private sector, increasing easy access to micro-finance and insurance, establishment of a livestock credit fund in the Central Bank are some of the important policy issues included in the document for smallholder dairy industry development.

\section{Dairy breeding}

An approved cattle mating plan was initiated in 1982 by the MoFL with an objective to develop first cross localxSahiwal or LocalxFriesian in periurban, urban and structured market area and to use these first cross bulls for upgrading the cattle of rural area. The mating plan was revised in 1997 rephrasing the former areas into intensive, where the use of pure bred Friesian or Sahiwal semen was approved. The rural breeding area was rephrased into extensive area and recommended continuation of using same breeding bulls. Finally, a breeding policy for increasing milk production was introduced by NLDP (2007) aiming at developing cows of 6000 litre lactation yield in 305 days lactation length through introducing of purebred Friesian semen of 9500 to 10,000 litres of lactation yield through short, medium and long term plan of actions. Pure breeding of RCC of the North-East undulated area, Pabna Cattle of Padma-Jamuna floodplain areas, Munshiganj cattle of Surma-Meghna floodplain area was also recommended. Production of first cross local with Murrah, NilliRavi or Mediterranean Buffalo bulls was approved in the plan.

\section{Dairy feeding and nutrition}

Limitation in land availability to fodder cultivation, quality control and spiralling prices over the time have been affecting dairy farmers with profit slashes. The public sector policy stated to have i) community-based fodder development programme, ii) supports for utilization and promotion of agro-industrial by-products, crop residues and unconventional feed resources, iii) promotion of market driven feed industries, iv) enacting feed quality control system, iv) rendering training to farmers and $v$ ) human resource development for further improvement of livestock including dairy.

\section{Health}

The policy document identifies that non-existence of disease surveillance system, public health support and quality control system as the major weaknesses exist in the public sector animal health services. Development of private, community-based and mobile veterinary services, strengthening veterinary research, human resources, establishment of autonomous quality control agency, strengthening veterinary public health services, control of trans-boundary animal diseases, and encouraging private veterinary diagnostic services are the major policies focussed in the NLDP (2007).

\section{Dairy research}

The BLRI, a state-run research organization under the MoFL, was entrusted to conduct research on livestock development of the country. The institute, started functioning in 1986 on a land area of 500 acres covered with greeneries, terrains and waterways in Savar, a suburb in 30 kilometer north-west of the capital city Dhaka. The BLRI is mandated to work on all disciplines of livestock development including dairy production and technology. Identifying the limited dairy research and development (RandD) capacity in the BLRI, the NLDP (2007) recommended establishment of a separate dairy research institute in the country. 


\section{A performance profile of Bangladesh dairying}

\section{Conclusion and way forwards}

Genetic upgradation of the local cows through decades of artificial breeding using the semen of high yielding exotic dairy bulls produces better yielding cows haphazardly without leading any breed development goals planned by the government. These animals are used in different production system of smallholder dairy, an enterprise of the land poor rural farmers get support of low quality feeds, and limited access to organized milk market. Action plans based on the approved public policy is essential for the development of domestic smallholder dairy for addressing growing milk demand in the present changing and challenging socio-economic conditions. Nevertheless, the following way forwards are important and required immediate follow ups for further development of the dairy industry in the country.

i. The responsibility of enhanced coordinated supports of both public and private sector may be given to an autonomous organization with clear authoritative mandate for setting policy priorities, institutional structures, priorities for research and extension, and for appropriation of adequate financial resources.

ii. Creation of an enabling environment for the multiplication of private dairy feed industry and community fodder production system.

iii. The private entrepreneurs remain active in dairy marketing may be given policy support for quick multiplication of dairy marketing supports.

iv. Action plans on dairy cattle development stated in National Livestock Development Policy (2007) should be formulated and implemented.

v. Review of the present domestic support system, identification of its strength and weakness; and establishment of easy credit and capital support to rural dairy farmers

vi. Strengthening coordinated backward services of the public and private sector (veterinary, disease diagnosis and quality control services; training and technology transfer)

vii. Capacity strengthening for dairy extension, research and education

viii. Development of human resources.

\section{Reference}

Baset MA (2012). Milk urea nitrogen concentration as a tool to monitor dietary protein status to dairy cow. PhD Thesis,
Bangladesh Agricultural University, Mymensingh, Bangladesh.

Baset MA, Huque KS, Sarker NR, Hossain MM, Islam MN (2013). Effect of feed base, season, genotype and days in milk on milk yield and composition of local and crossbred dairy cows, Journal of Bangladesh Livestock Research (in press).

BBS (2011). Bangladesh Bureau of Statistics, Statistical Year Book of Bangladesh, Statistics Division, Ministry of Planning, The Government of People's Republic of Bangladesh.

BER (2013). Bangladesh Economic Review, Finance Division, The Ministry of Finance, The Government of the People`s Republic of Bangladesh.

Bhuiyan AKFH, Hussain MM, Deb GK (2007). Indigenous Cattle Genetic Resources of Bangladesh and a Way Forward to their Development. Bangladesh Journal of Progressive Science and Technology, 5: 105-112.

BSTI (2008). Specification for Feeds and Feeding of Farm Animal and Pets, Bangladesh Standard and Testing Institute, BDS 1804; 116/A, Tegaon, Dhaka 1208, Bangladesh. CDVF Community-based Dairy Veterinary Foundation.

Das PK, Ali SZ, Islam ABMM, Roy BK (2003). A comparative study of productive and reproductive performance and estimates of heritability for economic traits in different genetic groups of cattle available at Baghabari Milk Pocket area of Bangladesh, Journal of Biological Science, 3: 726-740.

Deb GK, Huque KS, Al-faruque MH (2007). Genetic evaluation of Pabna Cattle at BLRI research farm, In Research Report, Animal production Research Division, BLRI, Savar, Dhaka, Bangladesh, P. 116-198

HIES (2010). A preliminary report on household income expenditure survey (HIES), Statistics Division, Ministry of Planning, The Government of the People's Republic of Bangladesh.

Hossain SMJ, Bhuiyan AKFH, Huque KS, Sarker NR, Sultana N, Alam MK (2011). Productive and reproductive potential of Red Chittagong cattle under in situ and ex situ conditions, Bangladesh Journal of Livestock Research, 18: 7-13.

Huque KS, Sarker NR (2013). Feeds and feeding of livestock in Bangladesh: performance, constraints and options forward; The paper is presented in a seminar on Livestock feeding 
and nutrition-global perspective and options for Bangladesh, BLRI, Bangladesh.

Huque KS (2006). Smallholder dairy development in Bangladesh - prospects and constraints; The paper is presented in the $4^{\text {th }}$ annual scientific conference and graduation ceremony of Chittagong Veterinary and Animal Sciences University, Chittagong, Bangladesh.

Huque KS and Islam MM (2006). Impact of Napier (Pennisetum purpurium) cultivation on the performance of smallholder dairy in a milk shed area of Bangladesh. Bangladesh J ournal of Livestock Research, 13: 30-38.

Huque KS, Rahman MM and Islam MR (2002). Farming characteristics of cooperative dairy production systems in Bangladesh. Bangladesh Journal of Livestock Research, 9: 17-29.

Jabbar MA, Hussain SS, Islam SMF, Amin MR, Khandaker MAMY, Bhuiyan AKFH, Ali SZ and Faruque O (2010). Stakeholder perspectives on breeding strategy and choice of breeds for livestock development in Bangladesh. Bangladesh Journal of Livestock Research, 39: 20-43.

Jalil MA, Huque KS, I slam MR and Miah G (2002). Study on the development of native buffaloes and their production system: A research report of Animal Production Research Division, Bangladesh Livestock Research Institute, Savar, Dhaka, Bangladesh.

Khan MKI, Miah G, Huque KS, Khatun MJ,Das A (2012). Economics and genetic evaluations of different dairy cattle breed under rural conditions in Bangladesh. Livestock Research for Rural Development, 24: 6-59.

Khan MKI, Miah G, Khatun MJ, Das A (2010). Economic values for different economic traits of Red Chittagong cows. Indian Journal of Animal Sciences, 80: 1138-40.

Majid MA, Nahar TN, Hossain M, Talukder Al (1998). Investigation on the strategy and impact of artificial insemination program and performance of crossbred cattle in Bangladesh, In Research report of 1992/931997/98 of Animal Production Research Division, Bangladesh Livestock Research Institute, Savar, Dhaka, P. 1-53.

Majid MA, Nahar TN, Talukder Al (1995). Evaluation of productive and reproductive performance of F1, F2 and F3 progeny of localxFriesian and SahiwalxFriesian cattle in the Savar dairy Farm, Research Report of
Animal production Research Division, Bangladesh Livestock Research Institute, Savar, Dhaka, Bangladesh, P. 486-519.

Mandal ANM (2013). Situation of processed dairy products in Bangladesh; A presentation of the workshop held in Bangkok, Food and Agriculture Organization.

NLDP (2007). National Livestock Development Policy, the Ministry of Fisheries and Livestock, the Government of the People's Republic of Bangladesh.

Rahman MM, Huque KS, Islam MR (2002). Study on the existing dairy production systems in Bangladesh; In Research Report 1997/98 to 2002/03 of Bangladesh Livestock Research Institute, Savar, Dhaka, Bangladesh, P. 380.

Roy BK, Huque KS, Rahman MR (2002). Study on indigenous milk product processing and preservation system in some selected regions of Bangladesh; Animal Production Research Division, BLRI, Bangladesh.

Roy BK, Huque KS, Sarker NR, Hossain SMJ, Rana MS, Munsi MN (2013). Study on growth and meat quality of native and Brahman crossbred bulls of different ages, Proceedings of the Annual Research Review Workshop, BLRI, Bangladesh.

Roy BK, Wadud A, Islam MN, Roy A, Bhuiyan MSA, Faruque S (2007). Quantitative analysis on productive and reproductive performance of different groups of dairy cows in army military dairy farms, Bangladesh Journal of Livestock Research, 14: 136- 145.

Sarker MSK, Huque KS, Sarker NR and Hossain MM (2013). Effects of genotypes, milking time, lactation, region, season and parity on milk composition of cows in Bangladesh (personal communication).

Sarker NR, Munsi N, Khatun R, and Alam MK (2013). Annual report of the coordinated project on contaminants and adulterants in food chain and their mitigation: BLRI Component; Financed by the Bangladesh Agricultural research Council; Animal Production Research Division, Bangladesh Livestock Research Institute, Savar, Dhaka, Bangladesh.

The Country Report of Bangladesh (2005). First report of the state of the world's animal genetic resources (AnGR), the Ministry of Fisheries and Livestock, The Government of the People's Republic of Bangladesh submitted to FAO of the United Nations. 